\title{
INSIGHTS INTO THE DISTRIBUTION OF SHALLOW-MARINE TO ESTUARINE EARLY MIOCENE OYSTERS FROM SOUTHWESTERN PATAGONIA: SEDIMENTOLOGIC AND STABLE ISOTOPE CONSTRAINTS
}

\author{
JOSÉ I. CUITIÑO,,${ }^{1,2 *}$ ROBERTO VENTURA SANTOS, ${ }^{3}$ and ROBERTO A. SCASSO 1,2 \\ ${ }^{1}$ Universidad de Buenos Aires, Departamento de Ciencias Geológicas, Facultad de Ciencias Exactas y Naturales, Intendente Guiraldes 2160 (C1428EHA), Ciudad \\ Autónoma de Buenos Aires, Argentina, joseignacio@gl.fcen.uba.ar, rscasso@gl.fcen.uba.ar; ${ }^{2}$ Instituto de Geociencias Básicas, Aplicadas y Ambientales de Buenos Aires, \\ Intendente Guiraldes 2160 (C1428EHA), Ciudad Autónoma de Buenos Aires, Argentina; ${ }^{3}$ Universidade de Brasília, Instituto de Geociências, Campus Universitário \\ Darcy Ribeiro CEP 70910-900 Brasilia, DF, Brazil, rventura@unb.br
}

\begin{abstract}
The lower Miocene Estancia 25 de Mayo Formation consists of shallowmarine to estuarine deposits that bear numerous oyster shell beds distributed throughout the succession. Facies analysis reveals that oysters grew in the nearshore paleoenvironments of both the lower Quién Sabe and the upper Bandurrias members. Two oyster species were identified: Crassostrea(?) hatcheri, distributed in the lower two thirds of the column, and Crassostrea orbignyi, distributed in the upper third of the column within the transition from marine to the fluvial deposits of the overlying Santa Cruz Formation. Petrographic, cathodoluminiscence, and carbon and oxygen stable isotope analyses of individual growth increments were performed on carbonate from all the oyster beds, together with consecutive time-series analyses for one specimen of each species. The isotopic composition of the shell seems to be associated with the microstructure of the growth increments. Selective diagenetic alteration affected chalky growth increments; whereas translucent (foliated and prismatic) growth increments are well preserved and can be used to infer paleoenvironmental conditions. Isotopic data indicate that $C$.(?) hatcheri lived in normal marine waters with a range of paleotemperatures from 10.6 to $20.5{ }^{\circ} \mathrm{C}$. Monospecific beds of this oyster are related to opportunistic and quick colonization of the sea bottom. More negative $\delta^{13} \mathrm{C}$ and $\delta^{18} \mathrm{O}$ values in $C$. orbignyi shells likely reflect decreased paleosalinities, and the resultant environmental stress controlled the development of these low-diversity oyster accumulations. The separate stratigraphic distribution of each species was therefore determined by the paleoenvironmental conditions.
\end{abstract}

\section{INTRODUCTION}

The mid-Cenozoic Patagoniense transgression of Patagonia is well known for its conspicuous beds of giant oysters, which have been interpreted to represent fully marine to estuarine environments (Bellosi, 1996; Parras and Casadío, 2005, 2006), although little is known about their modes of life. Calcareous fossils constitute an excellent tool to reconstruct ancient marine or estuarine environmental conditions by means of geochemical analyses of the preserved carbonate, particularly using carbon and oxygen isotopes (Wang et al., 1995; Jones and Quitmyer, 1996; Surge et al., 2001; Kirby, 2001; Goodwin et al., 2003; Gillikin et al., 2005; Schöne, 2008; Schöne and Surge, 2012). The proximity to land and the presence of semi-enclosed bodies of water in the coastal zone, together with the high sensitivity to sea-level fluctuations, make these environments susceptible to strong paleosalinity and paleotemperature variations, which impacts macrobenthos communities. Oysters are often present in these environments and are particularly useful for geochemical analyses for four reasons: (1) they

* Corresponding author.

Published Online: October 2013

Copyright @ 2013 , SEPM (Society for Sedimentary Geology) construct large heavy shells, especially during the Cenozoic (Nelson et al., 1983; Kirby, 2000, 2001; Parras and Casadío, 2006), with periodical growth increments; (2) the mineralogy of the shells is mainly calcite, giving the shell a high chemical stability during diagenesis; (3) the isotopic composition of the shell is apparently not subject to vital effects (Kirby et al., 1998; Surge et al., 2001), hence providing an accurate record of the isotopic composition and temperature of ancient seawaters; (4) oysters are able to inhabit environments with a wide salinity range, such as estuaries, deltas, and river mouths (Stenzel, 1971).

This paper aims to test if the distribution of two species of oysters, Crassostrea(?) hatcheri and C. orbignyi, is controlled by salinity or by any other factor such as temperature, nature of the substrate, water turbidity, or sedimentation rate in shallow-marine environments. The use of different shell microstructures as geochemical archives is tested. Facies analysis is combined with stable isotope analysis in order to develop a paleoenvironmental reconstruction.

Results discussed herein show that some monospecific oyster shell beds were formed in low-salinity environments; whereas others previously thought to have formed under salinity stress have normal marine isotope signals. We also show that chalky material, a porous calcitic microstructure commonly observed in oyster shells, deviates from the isotopic composition of the rest of the oyster microstructures. This is interpreted as a diagenetic effect, highlighting the need for care when sampling for isotopic analyses.

\section{STUDY AREA AND STRATIGRAPHIC SETTING}

The oyster-bearing beds analyzed here are part of the infill of the Austral or Magallanes Basin, located in southwestern Patagonia, at the southern tip of South America (Fig. 1A). The basin was active from the Early Cretaceous until the middle Miocene when it became uplifted due to Andean tectonics (Fosdick et al., 2011). The succession is well exposed near the southern margin of Lake Argentino, at the southwest of Santa Cruz province, Argentina (Fig. 1). Here, the sedimentary pile is composed of shallow-marine, deltaic, estuarine, and fluvial deposits spanning the Campanian to the middle Miocene. We studied the Estancia 25 de Mayo Formation (Cuitiño and Scasso, 2010) of early Miocene (Burdigalian) age (Cuitiño et al., 2012). This lithostratigraphic unit represents the Patagoniense transgression, a late Oligocene-early Miocene Atlantic marine invasion (Parras et al., 2012) that covered a huge region, mainly comprising the eastern portion of Patagonia, but occasionally reaching, in the west, up to the foothills of the Andes (Fig. 1). The 180-m-thick unit is composed of sandstone and heterolithic beds deposited in shallow-marine to estuarine environments, containing a rich and diverse marine fauna including bivalves, gastropods, echinoderms, crustaceans, brachiopods, and bryozoans (Casadío et al., 2000; Cuitiño and Scasso, 2010). Oysters are the most abundant fossils, and they are present from the base to the top of the 

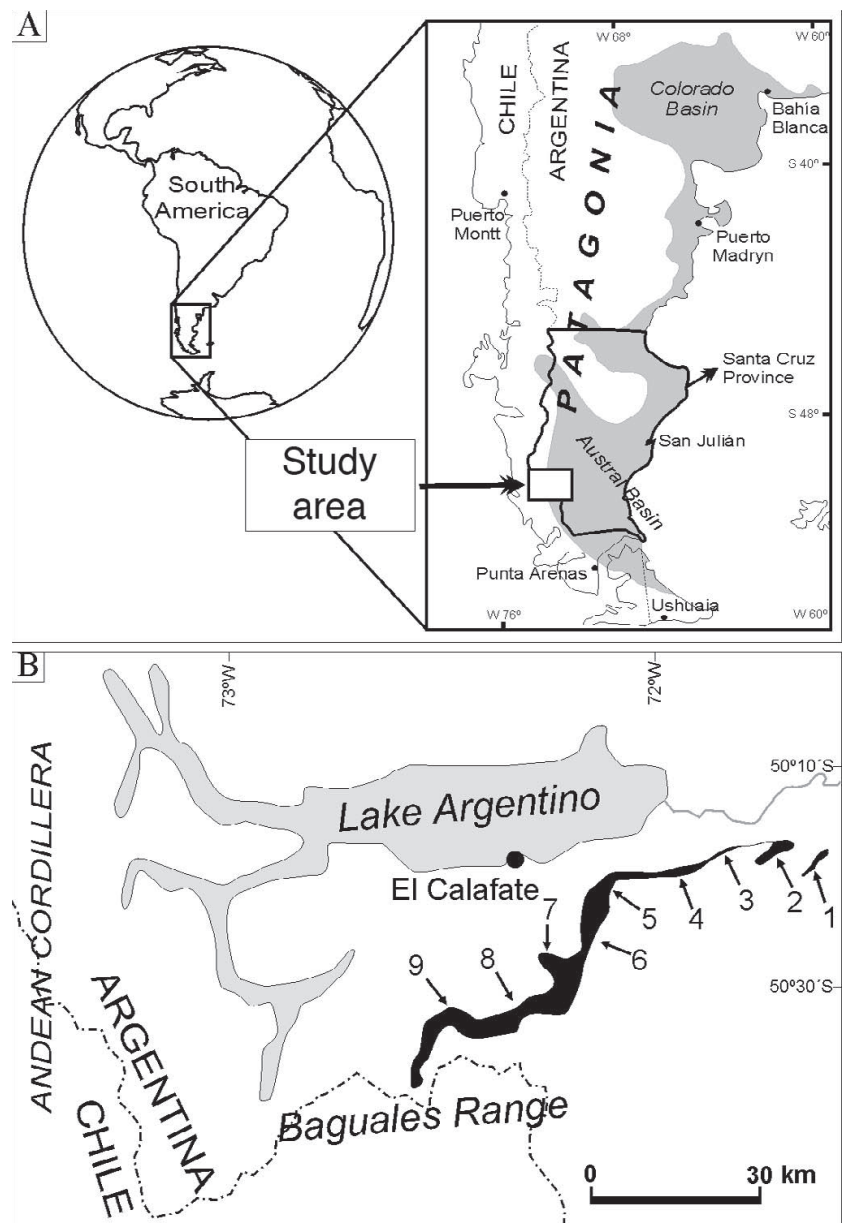

FIGURE 1-Location of the study area. A) Regional location. The shaded area represents the area flooded by the Patagoniense transgression after Malumián (1999). B) Sketch map with location of the studied sections, south of Lake Argentino. The black band corresponds to outcrop of the Estancia 25 de Mayo Formation. Numbers indicate measured sections as follows: 1 = Río Bote; 2 = Arroyo Los Perros; $3=$ Estancia Rincón Amigo; 4 = Estancia Quién Sabe; 5 = Cerro Dos Mellizos; $6=$ Estancia 25 de Mayo; $7=$ Arroyo Guanaquitos; 8 = Arroyo Bandurrias; $9=$ Sierra Cuncuna.

unit (Fig. 2). The lowermost beds of the Estancia 25 de Mayo Formation overlie the Río Leona Formation. The contact is interpreted to be a marine flooding surface with the underlying deposits interpreted to be a low-energy meandering fluvial system (Marenssi et al., 2005). The upper boundary of the Estancia 25 de Mayo Formation is characterized by estuarine-coastal deposits overlain by fluvial beds of the Santa Cruz Formation (Cuitiño and Scasso, 2010, 2013, fig. 2).

The Estancia 25 de Mayo Formation has been subdivided into two members (Cuitiño and Scasso, 2010): (1) The lower Quién Sabe Member is composed of fully bioturbated, massive, fine sandstone with some muddy or heterolithic intervals; (2) The upper Bandurrias Member is composed of coarser, cross-bedded sandstone with a higher amount of heterolithic intervals. The members are separated by a discontinuity that marks an abrupt change in the dominant sedimentary processes (Cuitiño, 2011, fig. 2).

Barreda et al. (2009) assigned a late Oligocene age to the upper part of the Río Leona Formation on the basis of palynology, and a Burdigalian age (early Miocene) (20-19 Ma) is estimated for the Estancia 25 de Mayo Formation from U-Pb ratios of zircon grains from pyroclastic intercalations and ${ }^{87} \mathrm{Sr} /{ }^{86} \mathrm{Sr}$ ratios from oyster shells (Cuitiño et al., 2012). The basal beds of the Santa Cruz Formation in this region have been dated as 18.8 Ma (Cuitiño et al., 2012).

\section{SEDIMENTARY PALEOENVIRONMENTS}

Nine stratigraphic and sedimentologic sections (Figs. 1-2) were studied in detail. Two well-exposed, stratigraphically complete sections (Estancia Quién Sabe and Arroyo Bandurrias) were selected for sampling the oyster shells.

\section{Facies Associations}

Sedimentary features observed in the field were used to define twelve lithofacies on the basis of texture, sedimentary structures, bioturbation, and types of fossil assemblages present. Eight lithofacies are dominated by siliciclastic sediment (Table 1); whereas four of them are dominated by bioclastic particles and are described separately (Table 2), with additional taphonomic attributes such as packing, abrasion, orientation, or articulation of the shell clasts. Although a lithofacies may contain shelly fossils, a bioclastic lithofacies is herein identified when the bioclastic fraction exceeds $30 \%$ of the rock volume. All lithofacies were grouped in seven Facies Associations (FA) on the basis of their stratigraphic order (Fig. 2).

FA1 is dominated by lithofacies Sm (massive sandstones) with intercalations of B1, B2, and B3 (bioclastic lithofacies). FA1 is the main component of the Quién Sabe Member, particularly in the northeastern portion of the study area, and it occasionally occurs in the Bandurrias Member (Fig. 2). The high degree of bioturbation recorded in Sm and the rich diversity of the marine fauna suggest a shallow-marine environment for this FA. Numerous levels of event bioclastic accumulations (lithofacies B2) suggest repeated episodes such as storms (Kidwell, 1991). The lack of primary sedimentary structures attributed to complete bioturbation $(\mathrm{Sm})$, the frequent bioclastic accumulations such as thick oyster beds (lithofacies B3), and the presence of residual shell beds (lithofacies B1) associated to erosive periods, indicates an overall low sedimentation rate. These features, combined with the grain size and the paleoecology of the fossil fauna, are consistent with deposition in a marine paleoenvironment that varied from the shoreface to a shallow inner shelf (Norris, 1986; Kidwell, 1991; Hampson and Storms, 2003; Parras and Casadío, 2005).

FA2 grades laterally and vertically into FA1 and is composed of equal proportions of lithofacies Sm and $\mathrm{F}$ (mudstone), with occasional intercalations of B2 and T (tuff). It is exclusive to the Quién Sabe Member and is the main component of this member in the southwestern part of the study area (Fig. 2). The high degree of bioturbation associated with the rich and diverse marine fauna indicates an open marine setting. The lack of significant erosional surfaces or reworked shell accumulations, together with the presence of a thick, fine-grained tuff bed (Cuitiño and Scasso, 2013), indicate a marine shelf with water depth enough to preclude storm wave influence on the bottom (Norris, 1986; Hampson and Storms, 2003).

FA3 appears exclusively, and in low proportion, in the upper beds of the Quién Sabe Member (Fig. 2). It consists of an interval a few meters thick that grades from lithofacies Sm to lithofacies Ht (heterolithic deposits), with an upward decrease in the degree of bioturbation and fossil content. Although no direct tidal indicators are found within this FA, the tidal influence is not discarded. It is interpreted as a nearshore deposit in which the macrobenthos decreased upward due to restricted environmental conditions such as reduced oxygenation, influence by freshwater input or temporary subaerial exposure in tidal flats (Pemberton et al., 2001).

FA4 is formed by lithofacies St (trough cross stratified sandstone), Sp (tabular cross stratified sandstone) and B4 (sandy bioclastic grainstone), with minor proportions of Sm and B1, being characterized by a general fining-upward trend. It lies above the regional discontinuity used by Cuitiño and Scasso (2010) to separate the Quién Sabe and Bandurrias members. Bioclastic lithofacies B4 is constituted by thick sets of cross-bedded sandstone beds rich in reworked shell debris. 


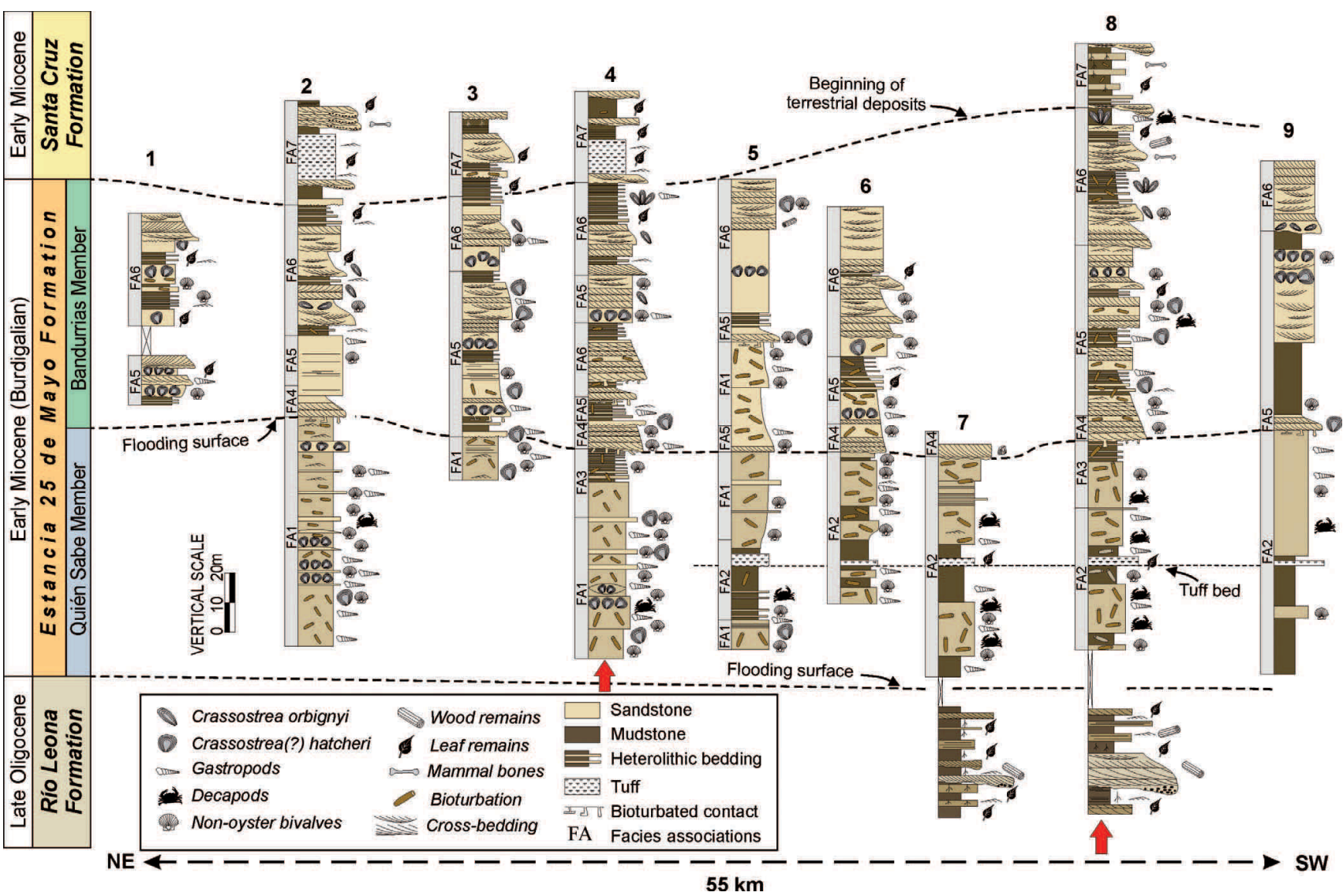

FIGURE 2-Sedimentary sections. Numbers at the top of each section indicate its position in Figure 1B. The tuff layer at the base of Estancia 25 de Mayo Formation and the discontinuity in the middle part of the unit support the correlation. Top of Río Leona Formation and base of Santa Cruz Formation are included. Red arrows indicate the sections selected for oyster sampling, and distribution of both oyster species is indicated.

Bidirectional paleocurrent directions occur in lithofacies B4, St, and Sp, suggesting strong tidal currents. A high energy, tide-dominated shallow-marine embayment is proposed as the depositional setting for this FA (e.g., Yoshida et al., 2004).

FA5 is exclusive to the Bandurrias Member and is composed of finingupward successions of lithofacies Sp, St, Sm, Sr (ripple-laminated sandstone), and $\mathrm{Ht}$, with sharp erosional bases. Marine fossil accumulations are dominated by Crassostrea(?) hatcheri and appear as thin beds of lithofacies B2 interbedded within Sm, and thick accumulations of B3 preserved normally at the base of the fining-upward successions. Bidirectional paleocurrent directions and mud drapes in foreset laminae, which characterize lithofacies Sp, St, and Sr, provide evidence of tidal influence (Nio and Yang, 1991). This FA is interpreted as subtidal sandbars grading upward into tidal flats, filling large tidal channels in a tidedominated estuary mouth (Weimer et al., 1982; Dalrymple et al., 1992).

FA6 is exclusive to the upper part of the Bandurrias Member. It is similar to FA5 but lacks the frequent shell beds and bioturbated intervals. Mud drapes are profuse in lithofacies Sp and St. Ht intervals are thicker than those of FA5 and inclined heterolithic stratification (IHS) is common. Fossil accumulations are dominated by Crassostrea orbignyi as lithofacies B3 (Fig. 3B) and B4 (Fig. 3D). Fining-upward trends, dominance of $\mathrm{Ht}$, presence of IHS, and mud drapes all suggest deposition in tidally influenced meandering channels and their associated tidal flats in the fluvial-tidal transition zone (Dalrymple and Choi, 2007; van den Berg et al., 2007). Low trace- and body-fossil diversity marks the influence of the freshwater discharge.

FA7 lies above FA6 and is part of the basal strata of the Santa Cruz Formation. It is composed of lithofacies Gm (massive conglomerate), $\mathrm{St}, \mathrm{Sp}$, and $\mathrm{F}$, together with thick, lenticular bodies of lithofacies $\mathrm{T}$. No marine fossils are recorded; however, plant debris, mammal bones, cutans, and root traces are common. Sand bodies are lenticular, with erosional bases covered by thin beds of lithofacies Gm, showing a general fining-upward trend. The dominance of mud over sand bodies, and the close relationship with underlying estuarine sediments (FA6), suggest a low-energy fluvial environment draining a low-gradient coastal plain (Miall, 1996; Makaske, 2001). The small lateral extension of the sand bodies suggests they may represent low-sinuosity fluvial channels (Gibling, 2006).

\section{Evolution of the Sedimentary System}

A complete transgressive-regressive cycle is recorded in the Estancia 25 de Mayo and Santa Cruz formations. The uppermost beds of the underlying Río Leona Formation (not included in the facies analysis) represent fluvial paleoenvironments, within-channel conglomerate bars and carbonaceous mudstone in the floodplains (Marenssi et al., 2005). Above, FA2 of the Estancia 25 de Mayo Formation is interpreted to represent deposition on a marine shelf, marking a sudden onset of marine sedimentation in the area.

Within the Quién Sabe Member FA1 is coarser grained and shows frequent reworked bioclastic accumulations, indicating accumulation in shallower conditions than FA2, which represents the deeper portion of the sea, with low wave and current activity, full bioturbation, and little reworking of shells (Fig. 2). The lateral facies gradation indicates that the sea was deeper to the southwest, as also suggested by some pyroclastic intercalations (Cuitiño and Scasso, 2013). Finally, the uppermost FA3 is interpreted to be a low-energy coastal setting, probably a tidal flat in a protected coastal marine environment. 
TABLE 1-Epiclastic lithofacies of the Estancia 25 de Mayo Formation.

\begin{tabular}{|c|c|c|c|c|c|c|}
\hline Code & Texture & Sedimentary structures & Bioturbation & Fossil content & Occurrence & Interpretation \\
\hline $\mathrm{Sm}$ & $\begin{array}{l}\text { Coarse silt to } \\
\text { medium sand. } \\
\text { Poor sorting }\end{array}$ & Massive & $\begin{array}{l}\text { High degree of bioturbation } \\
\text { and trace fossil diversity. } \\
\text { Planolites, Teichichnus, } \\
\text { Skolithos, Thalassinoides, } \\
\text { Scalichnus, Chondrites, } \\
\text { Scolicia }\end{array}$ & $\begin{array}{l}\text { High diversity marine fauna. } \\
\text { Oysters, pectinids and } \\
\text { other infaunal and } \\
\text { epifaunal bivalves; } \\
\text { gastropods; sand dollars; } \\
\text { decapod crustacean }\end{array}$ & $\begin{array}{l}30 \% \text { of the unit, and } 75 \% \\
\text { of the Quién Sabe Member }\end{array}$ & $\begin{array}{l}\text { Sedimentation in a nearshore } \\
\text { open marine environment. } \\
\text { Lack of sedimentary } \\
\text { structures due to intense } \\
\text { bioturbation }\end{array}$ \\
\hline St & $\begin{array}{l}\text { Medium to } \\
\text { coarse sand }\end{array}$ & $\begin{array}{l}\text { Trough cross stratification. } \\
\text { Occasionally with mud } \\
\text { drapes in foresets }\end{array}$ & $\begin{array}{l}\text { Scarce or absent. Mainly } \\
\text { Skolithos }\end{array}$ & $\begin{array}{l}\text { Scarce. Fragmentary } \\
\text { shells and plant debris }\end{array}$ & $\begin{array}{l}8 \% \text { of the unit and exclusive } \\
\text { to the Bandurrias Member } \\
(19 \%)\end{array}$ & $\begin{array}{l}\text { Migration of 3D subaqueous } \\
\text { sand dunes and bars }\end{array}$ \\
\hline $\mathrm{Sp}$ & $\begin{array}{l}\text { Medium to } \\
\text { coarse sand }\end{array}$ & $\begin{array}{l}\text { Tabular cross-stratification. } \\
\text { Mud drapes in foresets, } \\
\text { ubiquitous in some parts }\end{array}$ & $\begin{array}{l}\text { Scarce or absent. Mainly } \\
\quad \text { Skolithos }\end{array}$ & $\begin{array}{l}\text { Generally scarce, } \\
\text { although some } \\
\text { levels with abundant } \\
\text { shell debris }\end{array}$ & $\begin{array}{l}10 \% \text { of the unit and } \\
\text { exclusive to the } \\
\text { Bandurrias Member } \\
(20 \%)\end{array}$ & $\begin{array}{l}\text { Migration of 2D subaqueous } \\
\text { sand dunes and bars }\end{array}$ \\
\hline $\mathrm{Sr}$ & $\begin{array}{l}\text { Very fine to } \\
\text { coarse sand }\end{array}$ & $\begin{array}{l}\text { Symmetric and asymmetric } \\
\text { ripples. Cross-lamination. } \\
\text { Occasionally bipolar } \\
\text { paleocurrents }\end{array}$ & $\begin{array}{l}\text { Scarce or absent. } \\
\quad \text { Planolites }\end{array}$ & $\begin{array}{l}\text { Occasionally plant } \\
\text { debris }\end{array}$ & $\begin{array}{l}4 \% \text { of the unit and exclusive } \\
\text { to the Bandurrias Member } \\
(8 \%)\end{array}$ & $\begin{array}{l}\text { Migration of subaqueous } \\
\text { current or wave ripples. } \\
\text { Bipolar paleocurrents } \\
\text { indicate tidal action }\end{array}$ \\
\hline $\mathrm{Gm}$ & $\begin{array}{l}\text { Very coarse } \\
\text { sand to fine } \\
\text { gravel. Clast } \\
\text { supported }\end{array}$ & Massive or normal graded & Absent & Reworked shell debris & $2 \%$ of the unit & $\begin{array}{l}\text { Residual deposits associated } \\
\text { with erosive surfaces }\end{array}$ \\
\hline $\mathrm{F}$ & $\begin{array}{l}\text { Mainly silt and } \\
\text { scarce clay }\end{array}$ & $\begin{array}{l}\text { Massive, rarely laminated. } \\
\text { Cutans and roots traces in } \\
\text { parts }\end{array}$ & $\begin{array}{l}\text { Scarce to abundant. } \\
\text { Rootlets and tubes }\end{array}$ & $\begin{array}{l}\text { Well-preserved in-situ } \\
\text { marine shelly fauna. } \\
\text { Plant debris }\end{array}$ & $7 \%$ of the unit & $\begin{array}{l}\text { Deposition in marine, } \\
\text { transitional, and terrestrial } \\
\text { settings. Modification by } \\
\text { bioturbation or soil processes }\end{array}$ \\
\hline $\mathrm{Ht}$ & $\begin{array}{l}\text { Interlayered } \\
\text { mud and fine } \\
\text { to medium } \\
\text { sand }\end{array}$ & $\begin{array}{l}\text { Interbedding of horizontal or } \\
\text { inclined (IHS) muddy and } \\
\text { sandy layers. Ripples and } \\
\text { load structures common }\end{array}$ & $\begin{array}{l}\text { Moderate to absent. } \\
\text { Thalassinoides } \\
\text { common. Planolites }\end{array}$ & $\begin{array}{c}\text { Scarce marine and } \\
\text { brackish fauna }\end{array}$ & $\begin{array}{l}18 \% \text { of the unit, especially } \\
\text { in Bandurrias Member }\end{array}$ & $\begin{array}{l}\text { Alternation of tractive and } \\
\text { suspensive sedimentation } \\
\text { caused by tidal currents. IHS } \\
\text { produced during lateral } \\
\text { migration of tidal point bars }\end{array}$ \\
\hline $\mathrm{T}$ & $\begin{array}{l}\text { Very fine to } \\
\text { coarse tuffs }\end{array}$ & $\begin{array}{l}\text { Massive, parallel lamination, } \\
\text { ripple lamination, and cross- } \\
\text { bedding }\end{array}$ & Absent & Plant remains & $2 \%$ of the unit & $\begin{array}{l}\text { Events of explosive volcanism, } \\
\text { deposited in different } \\
\text { sedimentary settings. } \\
\text { Thoroughly studied in } \\
\text { Cuitiño and Scasso (2013) }\end{array}$ \\
\hline
\end{tabular}

FA4, FA5, and FA6 comprise the majority of the Bandurrias Member. FA4 represents a high-energy, tide-swept, open marine system, located above an erosion surface. FA5 and FA6 show fining-upward trends with erosional bases, and are interpreted as the infilling of tidal channels. FA5 is interpreted to represent sediment accumulation in wide channels of an estuary mouth due to the large lateral extent of the subtidal sandbars; whereas the smaller sand bodies of FA6 are interpreted as having formed in tidally influenced fluvial channels. FA5 contains abundant marine body and trace fossils; whereas FA6 shows scarce shelly material and trace fossils. Abundant mud drapes in

TABLE 2-Bioclastic lithofacies of the Estancia 25 de Mayo Formation.

\begin{tabular}{|c|c|c|c|c|c|c|}
\hline Code & Texture & Nature of strata & Sedimentary structures & Fossil content & Occurrence & Interpretation \\
\hline B1 & $\begin{array}{l}\text { Coarse sand to gravel-sized } \\
\text { shell debris. Clast supported. } \\
\text { Abraded and unabraded } \\
\text { bioclasts }\end{array}$ & $\begin{array}{l}\text { Few decimeters thick. Sharp } \\
\text { and plane or irregular base, } \\
\text { graded top. Tabular or } \\
\text { lenticular bodies }\end{array}$ & $\begin{array}{l}\text { Massive or normal } \\
\text { graded }\end{array}$ & $\begin{array}{l}\text { Mainly oysters. Abundant } \\
\text { reworked mollusks }\end{array}$ & $3 \%$ of the unit & $\begin{array}{l}\text { Residual concentration of } \\
\text { marine shells by removal of } \\
\text { finer epiclastic material }\end{array}$ \\
\hline B2 & $\begin{array}{l}\text { Nonabraded bioclasts, } \\
\text { occasionally articulated, } \\
\text { chaotic positions, loose } \\
\text { packing }\end{array}$ & $\begin{array}{l}\text { Centimetric beds. Base and } \\
\text { top usually transitional. } \\
\text { Tabular or wedging out } \\
\text { laterally }\end{array}$ & $\begin{array}{l}\text { Massive, rarely } \\
\text { imbrication }\end{array}$ & $\begin{array}{l}\text { Benthic shelly fauna, } \\
\text { especially bivalves. Low } \\
\text { diversity or monospecific, } \\
\text { especially oysters. } \\
\text { Pectinids common }\end{array}$ & $3 \%$ of the unit & $\begin{array}{l}\text { Sudden disruption and burial } \\
\text { of benthic communities by } \\
\text { high energy events (e.g., } \\
\text { storms) }\end{array}$ \\
\hline B3 & $\begin{array}{l}\text { Unabraded and well-preserved } \\
\text { shells, in life position or } \\
\text { slightly moved. Some bivalves } \\
\text { articulated. Shell sizes up to } \\
20 \mathrm{~cm} \text {. Sandy epiclastic or } \\
\text { bioclastic matrix }\end{array}$ & $\begin{array}{l}\text { Variable thickness, from few } \\
\text { centimeters to more than } \\
\text { s } 1 \mathrm{~m} \text {. Tabular or lenticular } \\
\text { (monticular) }\end{array}$ & $\begin{array}{l}\text { Crudely stratified to } \\
\text { massive }\end{array}$ & $\begin{array}{l}\text { Oysters compose the thicker } \\
\text { beds, frequently as } \\
\text { monospecific accumulations. } \\
\text { Others with high to low } \\
\text { diversity }\end{array}$ & $6 \%$ of the unit & $\begin{array}{l}\text { Colonization and vertical } \\
\text { growth of a benthic } \\
\text { community forming } \\
\text { biostromes }\end{array}$ \\
\hline B4 & $\begin{array}{l}\text { Bioclastic and epiclastic } \\
\text { fractions of similar grain size } \\
\text { (coarse sand to fine gravel), } \\
\text { although bioclasts may be } \\
\text { coarser. Clast supported. } \\
\text { Dispersed large shells occur }\end{array}$ & $\begin{array}{l}\text { Sharp, plane, or irregular } \\
\text { bases. Tabular beds. } \\
\text { Upward or lateral } \\
\text { transitions to lithofacies } \\
\text { Sp or St. Thicknesses } \\
\text { up to } 3 \mathrm{~m}\end{array}$ & $\begin{array}{l}\text { High- and low-angle } \\
\text { cross-bedding. } \\
\text { Parallel lamination }\end{array}$ & $\begin{array}{l}\text { Variable and well-mixed } \\
\text { marine shelly fauna. } \\
\text { Some beds dominated } \\
\text { by oyster or barnacle } \\
\text { fragments }\end{array}$ & $\begin{array}{l}4 \% \text {, exclusive to } \\
\text { Bandurrias } \\
\text { Member }\end{array}$ & $\begin{array}{l}\text { Migration of subaqueous dunes } \\
\text { or bars, composed of } \\
\text { bioclastic grains in hydraulic } \\
\text { equilibrium with epiclastic } \\
\text { grains }\end{array}$ \\
\hline
\end{tabular}



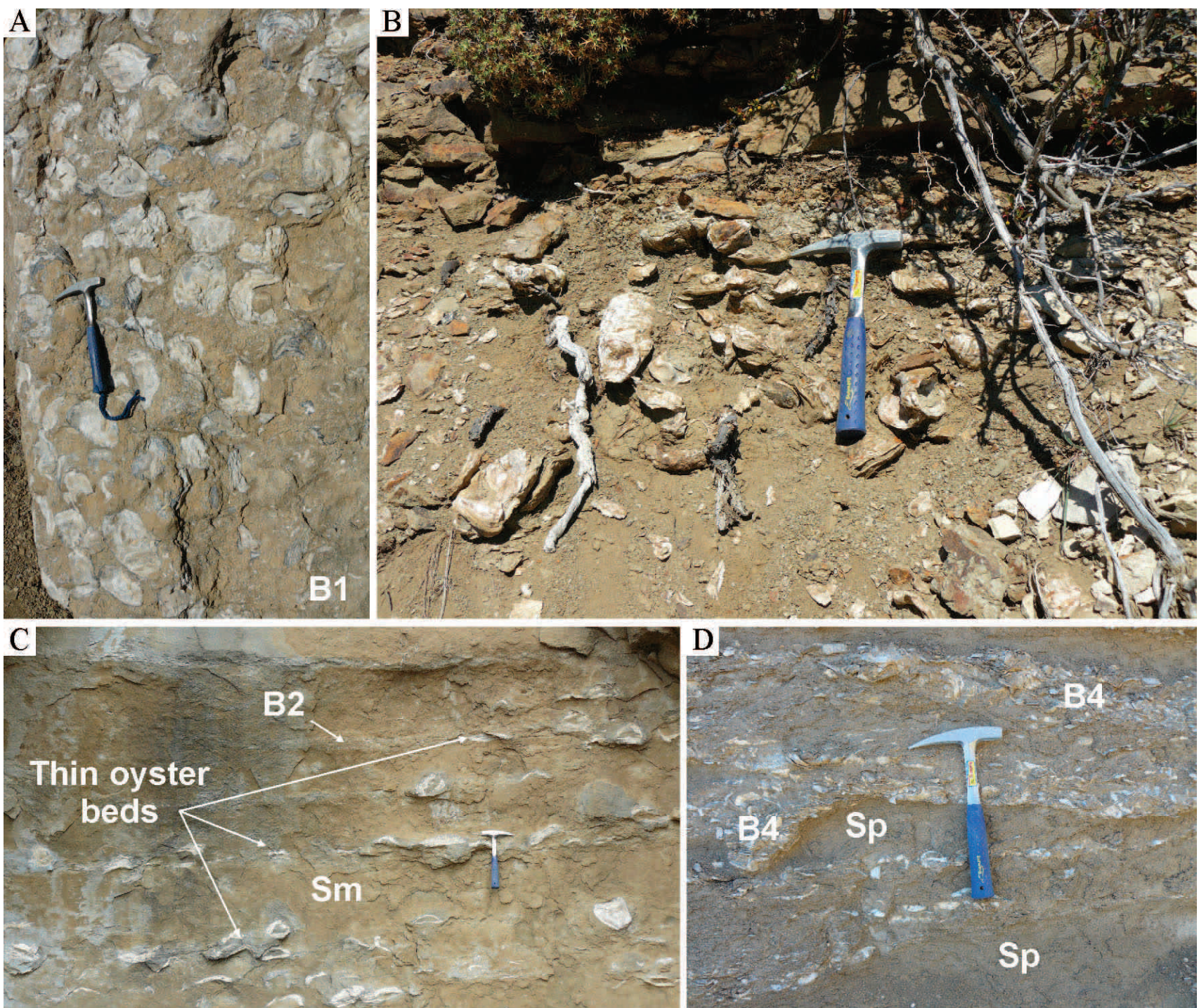

FIGURE 3-Field views of some oyster accumulations. A) Plan view of a C.(?) hatcheri accumulation. All are left valves showing similar orientation. Note their giant size and high degree of packing. Below, a reworked shell bed (lithofacies B1). B) Biogenic, moundlike accumulations of articulated and cemented C. orbignyi shells (lithofacies B3), similar to oyster biostromes described by Pufahl and James (2006). Note fine-grained sediments surrounding them. C) Thin beds of mostly articulated C.(?) hatcheri shells, interbedded with Sm and thin B2 beds with high biodiversity. D) Strongly reworked (lithofacies B4) monospecific accumulations of $C$. orbignyi interbedded with facies Sp, forming large bars (see also Tables 1-2).

foresets of FA6, and their absence in FA5, indicate that the former was deposited in a more landward position, within the tidal-fluvial transition zone of an estuary.

The lowermost beds of the Santa Cruz Formation, grouped in FA7, are interpreted as muddy floodplain and sandy, low-sinuosity fluvialchannel deposits. FA7 beds are intercalated with FA6 beds. They gradually become more abundant upward in the section and finally dominate as a result of the transition to a fully continental sedimentary system.

\section{OYSTER ACCUMULATIONS}

Oysters are the most frequent fossil in the Estancia 25 de Mayo Formation, forming different types of accumulations in both members (Figs. 2-3), with beds up to $2 \mathrm{~m}$ thick. Oysters with variable degrees of reworking form part of the four bioclastic lithofacies described (B1, B4, B2, and B3; Table 2), intercalated within FA1, FA4, FA5, and FA6.

Two species of oysters were identified: Crassostrea(?) hatcheri (Ortmann, 1897) and Crassostrea orbignyi (Ihering, 1897). Generic assignment of $C$.(?) hatcheri is currently being investigated (M. Griffin, personal communication, 2011). We, herein, follow Casadío et al (2000) and Parras and Casadío (2006) in tentative placement of this species in the genus Crassostrea. The species show external morphological differences with large, thick, and heavy shells for $C$.(?) hatcheri, and smaller, thinner, and rather irregularly shaped shells for $C$. orbignyi (Fig. 4). Crassostrea(?) hatcheri occurs in the Quién Sabe Member and in the lower half of the Bandurrias Member; whereas C. orbignyi appears only in the upper half of the Bandurrias Member, within the transition to the Santa Cruz Formation (Fig. 2). The same stratigraphic position of $C$. orbignyi has also been observed in other localities of southern Patagonia such as Monte León (Parras et al., 2008) and Lago Posadas in Santa Cruz Province. Co-occurrence of both species in a single bed was not recognized in any of the studied sections, even in those beds showing shell reworking.

Crassostrea(?) hatcheri commonly form thick beds of articulated, mostly nonattached, valves in life position. The valves show the commissure oriented in a horizontal to slightly inclined position (recliners), although some individuals were observed to occur in 


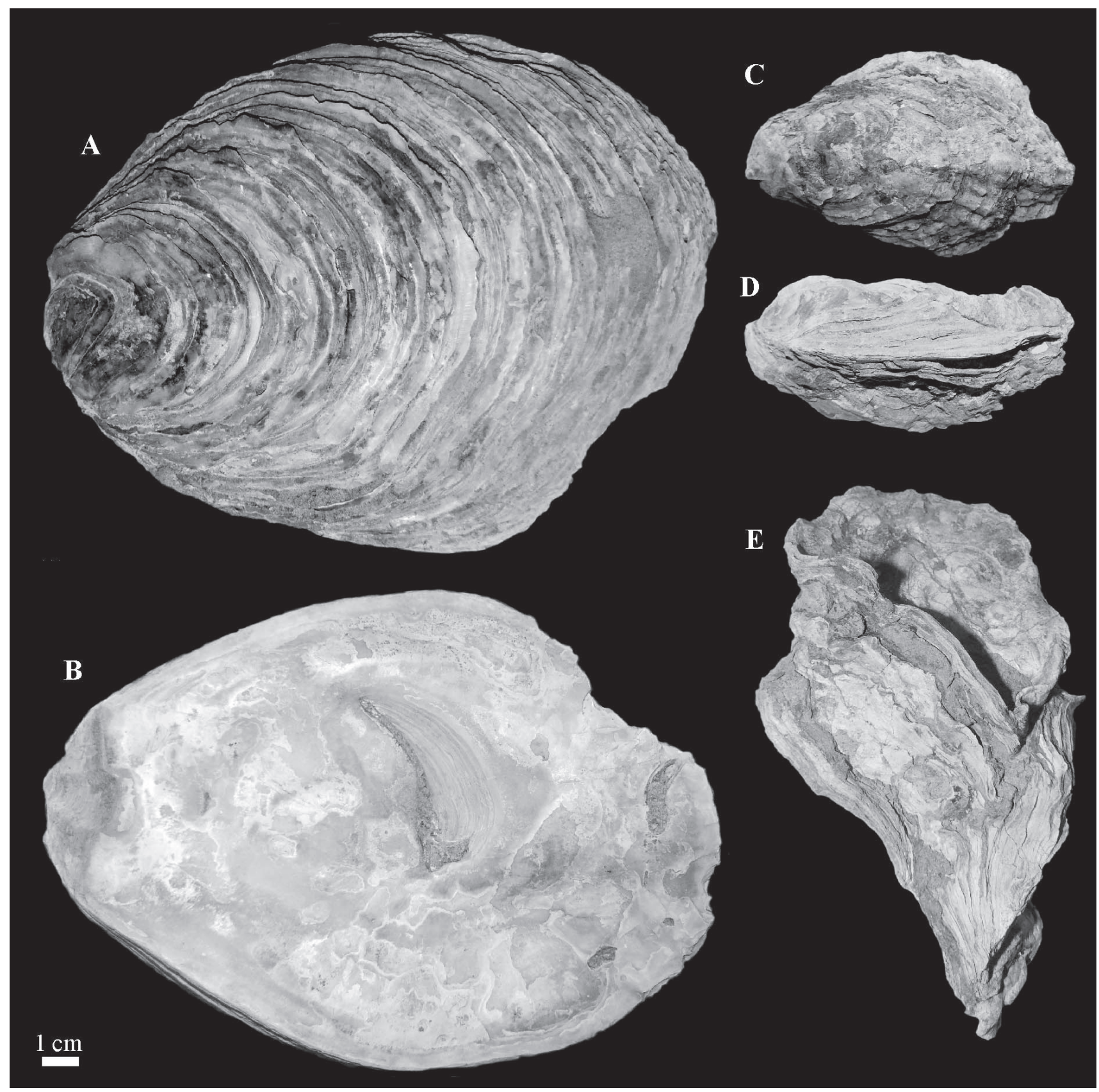

FIGURE 4-Oyster shells. A) Internal and B) external view of a large, right valve of Crassostrea(?) hatcheri (Ortmann, 1897). C-D) Articulated specimen of Crassostrea orbignyi (Ihering, 1897), where (C) shows the left valve and (D) a lateral view (right valve is upward). E) Cemented left valves of three specimens of C. orbignyi exhibiting growth-interference (xenomorphism). Scale bar is $1 \mathrm{~cm}$.

random orientations. A high degree of shell abrasion or bioerosion was observed in numerous reworked beds. Accumulations of this oyster are intercalated within FA1 within the Quién Sabe Member; whereas they lie mainly within FA5 in the Bandurrias Member. Shells are normally of large size, especially the convex to flat left valve, ranging from 10 to $25 \mathrm{~cm}$ in dorsoventral length, 15 to $5 \mathrm{~cm}$ in anteroposterior width, and 1 to $7 \mathrm{~cm}$ in thickness. Tabular beds can be traced between different sections (about 5 to $10 \mathrm{~km}$ apart); whereas rare lenticular beds pinch out in hundreds of meters. Some thick beds are internally composed of several thinner beds, marked by differences in the degree of packing, that laterally merge together to form a single thicker bed reaching up to $1.8 \mathrm{~m}$ thick (see fig. 6A of Cuitiño et al., 2012). Shell packing varies from isolated specimens (Fig. 3C) to shell supported, in which each shell is in contact (normally not attached) with its neighbors (Figs. 3AB). Thin, discrete, reworked levels or intercalations within thick beds show intensive bioerosion and encrustation (mainly barnacles) of shells such as those described by Parras and Casadío (2006). In general, accumulations of $C$.(?) hatcheri in FA1 are associated with rich and diverse macrobenthic communities including many species of bivalves, gastropods, echinoids, brachiopods, and crustaceans. However, accumulations in the Bandurrias Member (FA5) are monospecific or have low-diversity fossil assemblages largely dominated by oysters (Fig. 3A), including only a few other species of bivalves and gastropods.

Two types of accumulations of $C$. orbignyi were observed, most of them forming part of FA6; whereas a few appear in FA5 (Fig. 2). The first consists of in situ C. orbignyi specimens that appear cemented one 


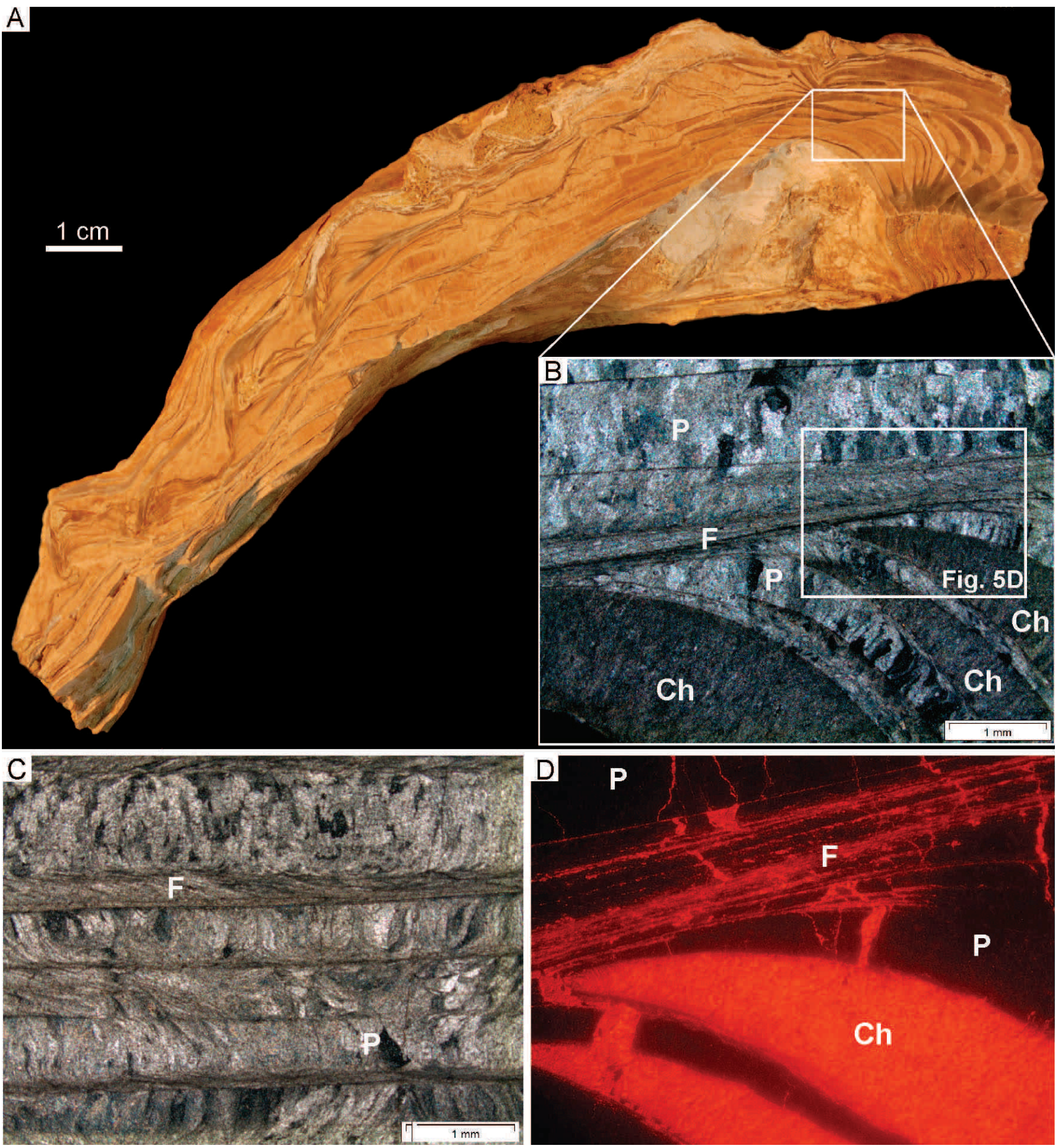

FIGURE 5-Petrographic features of oyster shells. A) Polished cross section of C. orbignyi. Intercalations of dark (translucent) and light (chalky) growth increments are easily visible near the umbonal region. Note predominance of chalky growth increments within the entire shell. B) Thin-section micrograph from the umbonal region of specimen pictured in view A. Prismatic $(=\mathrm{P})$, foliated $(=\mathrm{F})$ and chalky $(=\mathrm{Ch})$ microstructures can be recognized. Crossed nicols. C) Thin-section micrograph of a $C$. $($ ?) hatcheri shell showing 5 growth increments with predominance of foliated $(=\mathrm{F})$ and prismatic $(=\mathrm{P})$ microstructures. D) Cathodoluminescence image of the area detailed in view B. Note orange luminescene for chalky microstructures $(=\mathrm{Ch})$ and small veins, and nonluminescence for prismatic $(=\mathrm{P})$ microstructures. Foliated microstructures are partly bright in some areas affected by small veins across or parallel to layers.

to another, with horizontal- to vertically oriented commissure and highly irregular shell shapes due to mutual attachment (Fig. 4D). The shells form decimeter-thick, mound-shaped lenticular beds with tens of meters of lateral extent (Fig. 4C) and lie within mudstone or heterolithic intervals. Because of the vertical accretion of successive generations, these beds form biostromes similar to those described by
Pufahl and James (2006). The second type of accumulation is a reworked package of mainly disarticulated shells forming thick cosets of cross-stratified sets, in which shell material was in hydraulic equilibrium with medium to coarse sandstones (Fig. 3D). Although reworked, these beds are monospecific. Both types of accumulation are dominated by $C$. orbignyi and most of them are monospecific or contain 

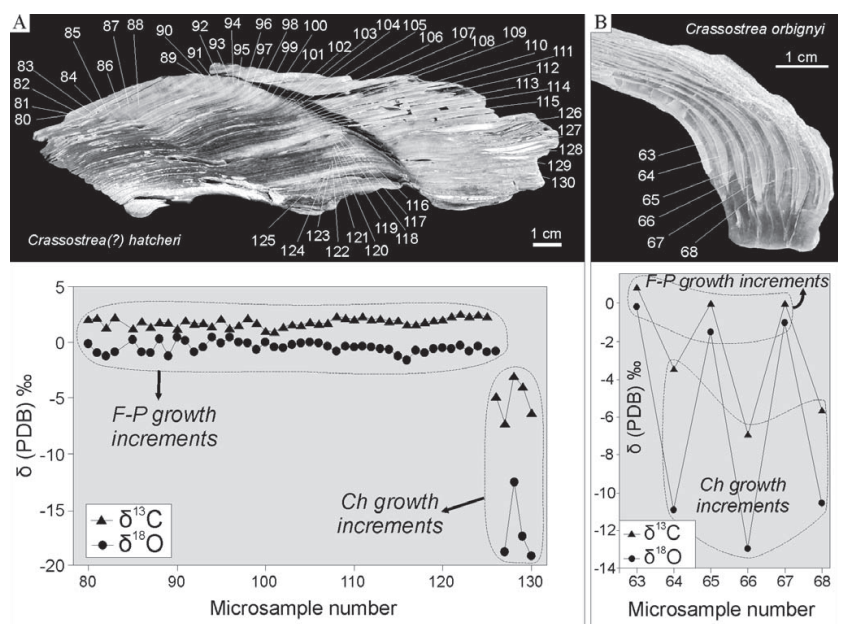

FIGURE 6-Serial isotopic analysis. A) Large and thick C.(?) hatcheri specimen (sample AB-XV) in which microsample positions are indicated (from 80 to 130). Note the similar isotopic values for the translucent growth increments (F-P) and the anomalous values for the chalky growth increments $(=\mathrm{Ch})$. B) Microsampling in $C$. orbignyi. Note clear alternation of dark (translucent) and light (chalky) growth increments and the different values for each microstructure.

few other taxa. Little or no encrustation and no bioerosion of the valves have been observed, except for some small bioerosion traces tentatively assigned to Radulichnus isp. The second type of $C$. orbignyi accumulation is interpreted as the result of reworking of the first type of accumulation.

The distribution of $C$.(?) hatcheri beds in the Quién Sabe Member indicates that the development of this oyster was favored by shallowmarine environments with low to moderate sedimentation rates and sandy or shelly bottoms (FA1), constantly agitated by wave action. The absence of this oyster in FA2 and FA3 indicates that these organisms did not inhabit deeper, mud-dominated environments. For FA3 sources of stress like salinity variations, subaerial exposure and high sedimentation rate are likely. In the Bandurrias Member C.(?) hatcheri grew mainly on sandy bottoms, although a few have been found in muddy sediments, associated with a fauna indicative of some degree of environmental stress. This oyster is commonly associated with low sedimentation rates during and after low-magnitude transgressive events. Facies analysis reveals a dynamic coastal system for the Bandurrias Member, with rapid changes in environmental conditions and portions of the succession showing evidence of high sedimentation rates (i.e., tidal channels). These, together with freshwater input into the coastal system, precluded C.(?) hatcheri from thriving in certain parts of the member. C. orbignyi accumulations are exclusive of the finegrained beds of the Bandurrias Member, which are interpreted as estuarine intertidal environments subjected to subaerial exposure and freshwater supply, where C.(?) hatcheri could not thrive.

\section{STABLE ISOTOPE ANALYSIS}

\section{Material and Laboratory Methods}

Whole and articulated shells of $C$.(?) hatcheri and C. orbignyi were sampled and the well-preserved umbonal region of the left valve was normally chosen. After cleaning, some large shells were covered with epoxy resin in order to strengthen the shell, and then cut along the dorsal-ventral (radial) plane. This surface was polished to observe the internal growth pattern (Figs. 5-6). Thin sections with the same orientation were made for polarizing and cathodoluminescence (CL) microscopy for three thick shells of each species. Additionally, scanning electron microscope (SEM) images were taken for selected shells.
Approximately 300 micrograms of carbonate were obtained with a dental drill of $0.5 \mathrm{~mm}$ diameter for stable oxygen and carbon isotope analysis. Individual growth increments showing uniform microstructure were sampled on the polished cross sections of the oysters. At least one such microsample was taken from an oyster at each oyster level (Fig. 7). Some levels are represented by one microsample of the translucent and others from the chalky growth increments. Thick oyster accumulations were sampled at different levels from base to top. Consecutive microsamples were taken across a shell of $C$.(?) hatcheri in order to produce a seasonally to annually resolved time series (Fig. 6A). A series of microsamples were taken from intercalations of translucent and chalky growth increments near the umbonal region of one C. orbignyi valve (Fig. 6B)

Carbon and oxygen isotope analysis were carried out at the Geochronos Lab at Brasilia University, Brazil. An aliquot of each sample was reacted with $100 \% \mathrm{H}_{3} \mathrm{PO}_{4}$ at $72{ }^{\circ} \mathrm{C}$ for 12 hours in glass vials. Before reaction, the vials containing samples were flushed with $\mathrm{He}$ in order to eliminate atmospheric gases. After reaction, the released $\mathrm{CO}_{2}$ masses were analyzed using a Thermo Fisher DELTA V Plus Isotope Ratio Mass Spectrometer and a Gas Bench II analyzer, from which the isotopic composition of $\delta^{13} \mathrm{C}$ and $\delta^{18} \mathrm{O}$ was calculated. In order to evaluate the analytical uncertainties, we analyzed four aliquots of the in-house carbonate reference materials BSB $\left(\delta^{13} \mathrm{C}=2.11 \%\right.$ \pm 0.06 , one standard deviation; $\delta^{18} \mathrm{O}=-1.98 \%$ \pm 0.06 , one standard deviation) and six aliquots of the in-house carbonate reference GEFA $\left(\delta^{13} \mathrm{C}=-5.33 \%\right.$ \pm 0.05 , one standard deviation; $\delta^{18} \mathrm{O}=-9.34 \%$ \pm 0.08 , one standard deviation) in the same batch of the samples. We also analyzed, together with the samples from the study interval, an aliquot of NBS18 $\left(\delta^{13} \mathrm{C}=-5.01 \pm 0.09 ; \delta^{18} \mathrm{O}=-23.07 \pm 0.07\right)$ and an aliquot of NBS19 $\left(\delta^{13} \mathrm{C}=2.22 \pm 0.06 ; \delta^{18} \mathrm{O}=-2.21 \pm 0.6\right)$. During the month in which analyses were performed, analyses of the international standards NBS18 $\left(\delta^{13} \mathrm{C}=-5.05 \% \pm 0.18 ; \delta^{18} \mathrm{O}=-22.98 \% 0 \pm\right.$ $0.17)$ and $\mathrm{NBS} 19\left(\delta^{13} \mathrm{C}=2.03 \% \circ \pm 0.04 ; \delta^{18} \mathrm{O}=-2.04 \%\right.$ \pm 0.16$)$ presented an acceptable reproducibility. Values in Table 3 are quoted in the standard \%oPDB notation and were obtained using a two-point calibration base on the in-house standards. Paleotemperatures were estimated using the equation of Epstein et al. (1953). This equation has three unknowns; temperature $\left(\mathrm{T}^{\circ}\right)$, oxygen isotopic composition of seawater $\left(\delta^{18} \mathrm{O}_{\mathrm{w}}\right)$, and isotopic composition of the shell carbonate $\left(\delta^{18} \mathrm{O}_{\mathrm{c}}\right)$. For calculation of the paleo- $\delta^{18} \mathrm{O}_{\mathrm{w}}$ we follow Wang et al. (1995) and Kirby et al. (1998), who assume cessation of calcification at temperatures below $11{ }^{\circ} \mathrm{C}$ in modern oysters. We are aware of the fact that cessation temperatures of shell growth likely have changed during $20 \mathrm{Ma}$ of evolution. However, for a first approximation, we assume that Miocene Crassostrea oysters had the same shutdown temperatures as their modern relatives. Following this assumption, the most positive $\delta^{18} \mathrm{O}_{\mathrm{c}}$ value measured $(0.48 \%$ ) would reflect the minimum water paleotemperature of $11{ }^{\circ} \mathrm{C}$ of precipitation of oyster-shell carbonate. Replacing both values in the paleotemperature equation, a $\delta^{18} \mathrm{O}_{\mathrm{w}}$ of $-1 \%$ o was obtained, which is the value used for paleotemperature calculations. This value is in agreement with those suggested for early Miocene ocean waters (Veizer et al., 1999; Zachos et al., 2001; Billups and Scharg, 2002).

\section{Results of the Microscope Study}

Observation of polished hand specimens and micropetrographic studies revealed a complex, rhythmic array of growth increments in the shells (Figs. 5-6). Two main types of microstructures (Carter, 1990) were identified. The first is composed mainly of translucent material (hereafter called translucent microstructures) when viewed under translucent light in naked-eye view, which revealed prismatic and foliated microstructures under the microscope (Fig. 5). Prismatic microstructures are composed of whitish to pale-yellow, coarsely prismatic calcite crystals elongated perpendicular to the shell surface; 


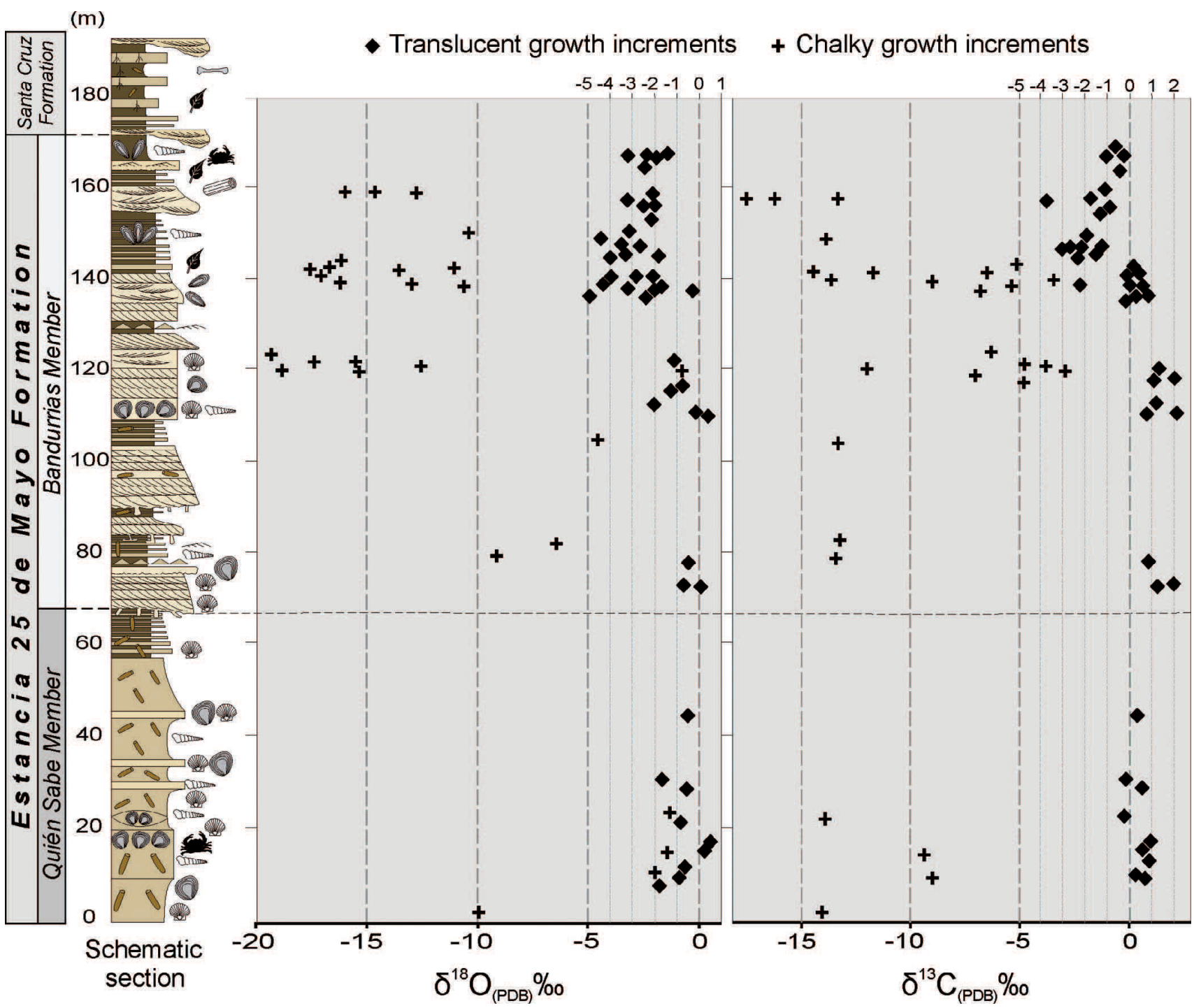

FIGURE 7-Schematic sedimentary column and whole isotope data set (serially sampled shell data is reduced to a mean point). Note the change in isotope values around 130 meters above the base, coincident with the change in oyster species (C. orbignyi above and C.(?) hatcheri beneath). Legend for the sedimentary column as in Figure 2.

whereas foliated microstructures are composed of dark-blue to darkgray, thin, strongly elongated calcite blades, which are oblique or parallel to the shell surface. The second type of microstructure is known as chalky, and is composed of a whitish, fine-grained carbonate, opaque in naked-eyed view and with a poorly developed crystalline structure under the microscope (Fig. 5). All three microstructures are common in oysters (Stenzel, 1971; Carter, 1990; Surge et al., 2001; Higuera-Ruiz and Elorza, 2009).

Cathodoluminiscence (CL) analyses were performed on some thin sections in order to evaluate the preservation of the biogenic carbonate Chalky growth increments showed a bright, orange luminescence (Fig. 5D) similar to that of sparry calcite cement in the rocks, veins, and other diagenetic precipitates. Translucent growth increments normally appeared nonluminescent except for some small fractures with small veins (Fig. 5D).

The distribution of microstructure types shows differences for each oyster species. Crassostrea(?) hatcheri shells are generally dominated by translucent growth increments. Lenticular chalky growth increments appear in some parts, especially near the ventral margin of the shell (Figs. 5-6). By contrast, C. orbignyi shell composition varies from nearly $50 \%$ of each microstructure type to dominant chalky material. In some shells composed almost entirely of chalky material, each chalky growth increment is separated by a thin foliated layer (growth lines).
The umbonal region near the ligamental area is always made of foliated material in both species (Fig. 5).

A subtle change in the shell microstructure in the sampled part of specimen $\mathrm{AB}-\mathrm{XV}$ occurs together with a $\delta^{18} \mathrm{O}$ decrease (Fig. $6 \mathrm{~A}$ ). The older, outer growth increments are composed mainly of prismatic microstructure (samples 80 to 100 in Fig. 6A) with lighter coloration; whereas the younger, inner growth increments are composed mainly of foliated microstructures (samples 100 to 125 in Fig. 6A) with darker coloration.

\section{Carbon and Oxygen Isotopes}

$\delta^{18} \mathrm{O}$ and $\delta^{13} \mathrm{C}$ for 128 calcite microsamples were determined from different shells in the sedimentary succession (Table 3 ). The data set spans a wide range of isotopic compositions, from -19.19 to $0.48 \%$ for $\delta^{18} \mathrm{O}$ and from -17.39 to $2.58 \%$ for $\delta^{13} \mathrm{C}$ (Fig. 8). Data from the translucent growth increments concentrate near $0 \%$ and define a low positive correlation for carbon and oxygen isotopes (Fig. 8). In contrast, data from the chalky growth increments have no correlation, large dispersion and negative values for both isotopes (Fig. 8).

The isotopic composition of both the translucent and chalky growth increments changes significantly through the sedimentary succession 
TABLE 3-Isotope data from oyster shells of the Estancia 25 de Mayo Formation. QS = Estancia Quien Sabe locality; AB = Arroyo Bandurrias locality. Paleotemperature calculations are given only for translucent growth increments of $C$.(?) hatcheri samples.

\begin{tabular}{|c|c|c|c|c|c|c|c|c|}
\hline Sample & Oyster & Microsample & Microstructure & $\delta^{13} \mathrm{C} \% o$ PDB & Stand. dev. & $\delta^{18} \mathrm{O} \%$ PDB & Stand. dev. & $\begin{array}{c}\text { Paleotemperature } \\
\left({ }^{\circ} \mathrm{C}\right)\end{array}$ \\
\hline QS-I & C.(?) hatcheri & 1 & Translucent & 0.61 & 0.08 & -0.85 & 0.06 & 15.9 \\
\hline QS-I & C.(?) hatcheri & 69 & Chalky & -9.15 & 0.09 & -1.93 & 0.05 & -- \\
\hline QS-I & C.(?) hatcheri & 2 & Translucent & 0.4 & 0.09 & -1.78 & 0.1 & 19.9 \\
\hline QS-II & C.(?) hatcheri & 3 & Translucent & 0.81 & 0.09 & -0.61 & 0.09 & 14.8 \\
\hline QS-III & C.(?) hatcheri & 71 & Chalky & -9.31 & 0.05 & -1.38 & 0.08 & -- \\
\hline QS-III & C.(?) hatcheri & 70 & Translucent & 0.98 & 0.09 & -0.09 & 0.06 & 12.7 \\
\hline QS-V & C.(?) hatcheri & 4 & Translucent & 0.62 & 0.08 & 0.43 & 0.11 & 10.6 \\
\hline QS-V & C.(?) hatcheri & 5 & Translucent & 0.89 & 0.13 & 0.28 & 0.13 & 11.2 \\
\hline QS-VII & C.(?) hatcheri & 6 & Chalky & -13.8 & 0.08 & -1.31 & 0.14 & -- \\
\hline QS-VII & C.(?) hatcheri & 72 & Translucent & 0.62 & 0.06 & -1.39 & 0.05 & 18.2 \\
\hline QS-VII & C.(?) hatcheri & 7 & Translucent & -0.15 & 0.08 & -0.93 & 0.06 & 16.2 \\
\hline QS-VIII & C.(?) hatcheri & 73 & Translucent & 0.36 & 0.05 & 0.11 & 0.06 & 11.9 \\
\hline QS-VIII & C.(?) hatcheri & 8 & Translucent & 0.58 & 0.12 & -0.66 & 0.11 & 15.1 \\
\hline QS-IX & C.(?) hatcheri & 9 & Translucent & -0.16 & 0.06 & -1.56 & 0.12 & 19 \\
\hline QS-X & C.(?) hatcheri & 74 & Translucent & 0.83 & 0.06 & -0.74 & 0.04 & 15.4 \\
\hline QS-X & C.(?) hatcheri & 10 & Translucent & 0.29 & 0.05 & -0.53 & 0.07 & 14.5 \\
\hline QS-XI & C.(?) hatcheri & 11 & Translucent & 2 & 0.04 & 0.15 & 0.06 & 11.7 \\
\hline QS-XI & C.(?) hatcheri & 12 & Translucent & 1.24 & 0.05 & -0.59 & 0.05 & 14.8 \\
\hline QS-XIII & C.(?) hatcheri & 75 & Chalky & -13.4 & 0.06 & -9.14 & 0.06 & -- \\
\hline QS-XIII & C.(?) hatcheri & 13 & Chalky & -13.17 & 0.08 & -6.48 & 0.14 & -- \\
\hline QS-XV & C.(?) hatcheri & 76 & Translucent & 2.03 & 0.09 & -1.18 & 0.08 & 17.3 \\
\hline QS-XV & C.(?) hatcheri & 14 & Translucent & 1.26 & 0.04 & -1.91 & 0.07 & 20.5 \\
\hline QS-XVII & C.(?) hatcheri & 77 & Chalky & -11.92 & 0.08 & -15.29 & 0.05 & -- \\
\hline QS-XVII & C.(?) hatcheri & 78 & Translucent & 1.48 & 0.05 & -1.08 & 0.06 & 16.8 \\
\hline QS-XVII & C.(?) hatcheri & 15 & Translucent & 1.38 & 0.05 & -1.11 & 0.08 & 17 \\
\hline QS-XVIII (1) & C. orbignyi & 16 & Translucent & 0.84 & 0.03 & -2.4 & 0.1 & -- \\
\hline QS-XVIII (1) & C. orbignyi & 17 & Chalky & -7.63 & 0.1 & -14.55 & 0.14 & -- \\
\hline QS-XVIII (2) & C. orbignyi & 18 & Translucent & -0.12 & 0.1 & -0.29 & 0.12 & -- \\
\hline QS-XVIII (3) & C. orbignyi & 19 & Chalky & -9.03 & 0.08 & -16.07 & 0.05 & -- \\
\hline QS-XIX (2) & C. orbignyi & 63 & Translucent & 0.89 & 0.04 & -0.22 & 0.05 & -- \\
\hline QS-XIX (2) & C. orbignyi & 64 & Chalky & -3.48 & 0.05 & -10.99 & 0.06 & -- \\
\hline QS-XIX (2) & C. orbignyi & 65 & Translucent & -0.01 & 0.09 & -1.51 & 0.05 & -- \\
\hline QS-XIX (2) & C. orbignyi & 66 & Chalky & -6.9 & 0.08 & -13 & 0.06 & -- \\
\hline QS-XIX (2) & C. orbignyi & 67 & Translucent & -0.01 & 0.07 & -1.08 & 0.06 & -- \\
\hline QS-XIX (2) & C. orbignyi & 68 & Chalky & -5.64 & 0.06 & -10.59 & 0.06 & -- \\
\hline QS-XIX (2) & C. orbignyi & 20 & Chalky & -5.57 & 0.08 & -13.74 & 0.09 & -- \\
\hline QS-XIX (3) & C. orbignyi & 21 & Translucent & 0.38 & 0.07 & -1.79 & 0.06 & -- \\
\hline QS-XX (3) & C. orbignyi & 22 & Translucent & 0.25 & 0.08 & -4.21 & 0.12 & -- \\
\hline QS-XX (1) & C. orbignyi & 23 & Translucent & -0.15 & 0.07 & -3.93 & 0.06 & -- \\
\hline QS-XXI & C. orbignyi & 24 & Chalky & -6.88 & 0.06 & -17.26 & 0.13 & -- \\
\hline QS-XXIII (2) & C. orbignyi & 25 & Translucent & -1.12 & 0.05 & -2.13 & 0.09 & -- \\
\hline QS-XXIII (2) & C. orbignyi & 26 & Chalky & -17.39 & 0.04 & -16.01 & 0.06 & -- \\
\hline QS-XXIII (4) & C. orbignyi & 27 & Translucent & -1.79 & 0.11 & -2.44 & 0.07 & -- \\
\hline QS-XXIII (1) & C. orbignyi & 28 & Translucent & -0.93 & 0.07 & -2.33 & 0.05 & -- \\
\hline QS-XXIII (1) & C. orbignyi & 29 & Chalky & -13.81 & 0.12 & -12.71 & 0.06 & -- \\
\hline QS-XXIII (5) & C. orbignyi & 30 & Chalky & -16.37 & 0.05 & -14.67 & 0.06 & -- \\
\hline QS-XXIII (5) & C. orbignyi & 31 & Translucent & -1.22 & 0.08 & -1.96 & 0.05 & -- \\
\hline QS-XXIV & C. orbignyi & 32 & Chalky & -3.7 & 0.06 & -3.22 & 0.05 & -- \\
\hline AB-II & C.(?) hatcheri & 33 & Chalky & -14.04 & 0.05 & -9.99 & 0.1 & -- \\
\hline AB-IX & C.(?) hatcheri & 34 & Translucent & 0.88 & 0.03 & -0.37 & 0.07 & 13.8 \\
\hline AB-X & C.(?) hatcheri & 35 & Translucent & 0.77 & 0.06 & 0.37 & 0.07 & 10.9 \\
\hline AB-X & C.(?) hatcheri & 36 & Chalky & -13.35 & 0.07 & -4.62 & 0.04 & -- \\
\hline AB-XI & C.(?) hatcheri & 37 & Translucent & 2.13 & 0.06 & -0.18 & 0.05 & 13.1 \\
\hline $\mathrm{AB}-\mathrm{XV}$ & C.(?) hatcheri & 38 & Translucent & 1.15 & 0.05 & -1.01 & 0.12 & 16.5 \\
\hline$A B-X V$ & C.(?) hatcheri & 39 & Translucent & 2.12 & 0.11 & -0.88 & 0.11 & 16 \\
\hline$A B-X V$ & C.(?) hatcheri & 40 & Chalky & -4.75 & 0.08 & -15.49 & 0.11 & -- \\
\hline AB-XVI (1) & C. orbignyi & 41 & Chalky & -13.34 & 0.04 & -16.28 & 0.06 & -- \\
\hline AB-XVI (1) & C. orbignyi & 42 & Chalky & -2.21 & 0.05 & -4.84 & 0.04 & -- \\
\hline AB-XVI (4) & C. orbignyi & 43 & Chalky & 0.53 & 0.05 & -2.11 & 0.07 & -- \\
\hline AB-XVI (4) & C. orbignyi & 44 & Chalky & -11.87 & 0.11 & -16.61 & 0.04 & -- \\
\hline AB-XVI (3) & C. orbignyi & 45 & Translucent & 0.13 & 0.06 & -3.07 & 0.07 & -- \\
\hline AB-XVI (3) & C. orbignyi & 46 & Translucent & 0.48 & 0.04 & -3.02 & 0.08 & -- \\
\hline AB-XVI (2) & C. orbignyi & 47 & Chalky & -14.3 & 0.05 & -17.21 & 0.07 & -- \\
\hline AB-XVI (2) & C. orbignyi & 48 & Translucent & 0.55 & 0.05 & -2 & 0.04 & -- \\
\hline AB-XVII (1) & C. orbignyi & 49 & Tranclucent & -2.23 & 0.04 & -3.28 & 0.07 & -- \\
\hline AB-XVII (1) & C. orbignyi & 50 & Chalky & -7.12 & 0.05 & -8.12 & 0.05 & -- \\
\hline AB-XVII (2) & C. orbignyi & 51 & Translucent & -2.18 & 0.09 & -3.45 & 0.07 & -- \\
\hline AB-XVII (2) & C. orbignyi & 52 & Chalky & -14.11 & 0.06 & -10.61 & 0.07 & -- \\
\hline AB-XVII (3) & C. orbignyi & 53 & Translucent & -1.89 & 0.05 & -3.88 & 0.03 & -- \\
\hline AB-XVII (3) & C. orbignyi & 54 & Translucent & -1.42 & 0.08 & -2.67 & 0.03 & -- \\
\hline
\end{tabular}


TABLE 3-Continued

\begin{tabular}{|c|c|c|c|c|c|c|c|c|}
\hline Sample & Oyster & Microsample & Microstructure & $\delta^{13} \mathrm{C} \%$ PDB & Stand. dev. & $\delta^{18} \mathrm{O} \%$ PDB & Stand. dev. & $\begin{array}{c}\text { Paleotemperature } \\
\left({ }^{\circ} \mathrm{C}\right)\end{array}$ \\
\hline AB-XVII (3) & C. orbignyi & 56 & Translucent & -2.61 & 0.05 & -3.52 & 0.05 & -- \\
\hline AB-XVII (3) & C. orbignyi & 57 & Translucent & -1.28 & 0.09 & -1.86 & 0.04 & -- \\
\hline AB-XVII (3) & C. orbignyi & 58 & Translucent & -2.96 & 0.06 & -4.52 & 0.06 & -- \\
\hline AB-XVIII (1) & C. orbignyi & 59 & Translucent & -0.65 & 0.07 & -1.83 & 0.07 & -- \\
\hline AB-XVIII (3) & C. orbignyi & 60 & Translucent & -0.44 & 0.06 & -3.29 & 0.05 & -- \\
\hline AB-XVIII (3bis) & C. orbignyi & 61 & Translucent & -0.3 & 0.09 & -2.44 & 0.04 & -- \\
\hline AB-XVIII (4) & C. orbignyi & 62 & Translucent & -0.95 & 0.09 & -1.51 & 0.06 & -- \\
\hline AB-IX & C.(?) hatcheri & 79 & Translucent & 1.79 & 0.05 & -0.08 & 0.07 & 12.7 \\
\hline$A B-X V$ & C.(?) hatcheri & 80 & Translucent & 1.96 & 0.09 & -0.13 & 0.05 & 12.8 \\
\hline$A B-X V$ & C.(?) hatcheri & 81 & Translucent & 2.14 & 0.07 & -0.92 & 0.06 & 16.2 \\
\hline$A B-X V$ & C.(?) hatcheri & 82 & Translucent & 1.29 & 0.07 & -1.21 & 0.07 & 17.4 \\
\hline$A B-X V$ & C.(?) hatcheri & 83 & Translucent & 2.23 & 0.07 & -0.86 & 0.03 & 15.9 \\
\hline$A B-X V$ & C.(?) hatcheri & 85 & Translucent & 1.21 & 0.1 & 0.26 & 0.05 & 11.3 \\
\hline$A B-X V$ & C.(?) hatcheri & 86 & Translucent & 1.95 & 0.05 & -0.87 & 0.06 & 15.9 \\
\hline$A B-X V$ & C.(?) hatcheri & 87 & Translucent & 1.40 & 0.06 & -0.95 & 0.04 & 16.3 \\
\hline$A B-X V$ & C.(?) hatcheri & 88 & Translucent & 1.81 & 0.08 & 0.34 & 0.05 & 11 \\
\hline$A B-X V$ & C.(?) hatcheri & 89 & Translucent & 1.81 & 0.05 & -1.23 & 0.04 & 17.5 \\
\hline$A B-X V$ & C.(?) hatcheri & 90 & Translucent & 1.26 & 0.09 & 0.47 & 0.04 & 10.5 \\
\hline$A B-X V$ & C.(?) hatcheri & 91 & Translucent & 1.98 & 0.08 & 0.18 & 0.06 & 11.6 \\
\hline$A B-X V$ & C.(?) hatcheri & 92 & Translucent & 1.67 & 0.09 & -0.84 & 0.06 & 15.8 \\
\hline$A B-X V$ & C.(?) hatcheri & 93 & Translucent & 1.75 & 0.05 & -0.43 & 0.05 & 14.1 \\
\hline$A B-X V$ & C.(?) hatcheri & 94 & Translucent & 1.43 & 0.08 & 0.44 & 0.04 & 10.6 \\
\hline$A B-X V$ & C.(?) hatcheri & 95 & Translucent & 2.13 & 0.07 & -0.06 & 0.05 & 12.6 \\
\hline$A B-X V$ & C.(?) hatcheri & 96 & Translucent & 1.28 & 0.06 & 0.48 & 0.08 & 10.4 \\
\hline$A B-X V$ & C.(?) hatcheri & 97 & Translucent & 1.57 & 0.05 & 0.05 & 0.09 & 12.1 \\
\hline$A B-X V$ & C.(?) hatcheri & 98 & Translucent & 2.19 & 0.13 & -0.08 & 0.05 & 12.7 \\
\hline$A B-X V$ & C.(?) hatcheri & 99 & Translucent & 1.76 & 0.06 & -0.61 & 0.03 & 14.9 \\
\hline$A B-X V$ & C.(?) hatcheri & 100 & Translucent & 1.03 & 0.08 & 0.05 & 0.07 & 12.1 \\
\hline $\mathrm{AB}-\mathrm{XV}$ & C.(?) hatcheri & 101 & Translucent & 0.98 & 0.06 & -0.4 & 0.05 & 14 \\
\hline$A B-X V$ & C.(?) hatcheri & 102 & Translucent & 1.4 & 0.05 & -0.5 & 0.07 & 14.4 \\
\hline$A B-X V$ & C.(?) hatcheri & 103 & Translucent & 1.61 & 0.06 & -0.19 & 0.12 & 13.1 \\
\hline$A B-X V$ & C.(?) hatcheri & 104 & Translucent & 1.58 & 0.1 & -0.06 & 0.06 & 12.6 \\
\hline$A B-X V$ & C.(?) hatcheri & 105 & Translucent & 1.86 & 0.07 & 0.04 & 0.05 & 12.2 \\
\hline$A B-X V$ & C.(?) hatcheri & 106 & Translucent & 1.68 & 0.06 & -0.09 & 0.04 & 12.7 \\
\hline$A B-X V$ & C.(?) hatcheri & 107 & Translucent & 1.76 & 0.05 & -0.36 & 0.05 & 13.8 \\
\hline$A B-X V$ & C.(?) hatcheri & 108 & Translucent & 2.37 & 0.08 & -0.79 & 0.05 & 15.6 \\
\hline$A B-X V$ & C.(?) hatcheri & 109 & Translucent & 2.22 & 0.08 & -0.39 & 0.08 & 13.9 \\
\hline$A B-X V$ & C.(?) hatcheri & 110 & Translucent & 2.03 & 0.08 & -0.42 & 0.1 & 14 \\
\hline$A B-X V$ & C.(?) hatcheri & 111 & Translucent & 2.36 & 0.08 & -0.39 & 0.05 & 13.9 \\
\hline$A B-X V$ & C.(?) hatcheri & 112 & Translucent & 2.05 & 0.04 & -0.46 & 0.06 & 14.2 \\
\hline$A B-X V$ & C.(?) hatcheri & 113 & Translucent & 2.14 & 0.08 & -0.59 & 0.07 & 14.8 \\
\hline$A B-X V$ & C.(?) hatcheri & 114 & Translucent & 1.94 & 0.08 & -0.63 & 0.08 & 14.9 \\
\hline$A B-X V$ & C.(?) hatcheri & 115 & Translucent & 1.99 & 0.08 & -1.27 & 0.09 & 17.7 \\
\hline$A B-X V$ & C.(?) hatcheri & 116 & Translucent & 1.60 & 0.11 & -1.62 & 0.05 & 19.2 \\
\hline$A B-X V$ & C.(?) hatcheri & 117 & Translucent & 1.66 & 0.04 & -0.76 & 0.07 & 15.5 \\
\hline$A B-X V$ & C.(?) hatcheri & 118 & Translucent & 1.83 & 0.07 & -0.98 & 0.08 & 16.4 \\
\hline$A B-X V$ & C.(?) hatcheri & 119 & Translucent & 1.96 & 0.04 & -0.59 & 0.07 & 14.8 \\
\hline$A B-X V$ & C.(?) hatcheri & 120 & Translucent & 2.07 & 0.04 & -0.47 & 0.09 & 14.3 \\
\hline$A B-X V$ & C.(?) hatcheri & 121 & Translucent & 2.38 & 0.08 & -0.6 & 0.07 & 14.8 \\
\hline$A B-X V$ & C.(?) hatcheri & 122 & Translucent & 2.58 & 0.07 & -0.26 & 0.04 & 13.4 \\
\hline$A B-X V$ & C.(?) hatcheri & 123 & Translucent & 2.33 & 0.08 & -0.79 & 0.09 & 15.6 \\
\hline$A B-X V$ & C.(?) hatcheri & 124 & Translucent & 2.49 & 0.05 & -0.36 & 0.05 & 13.8 \\
\hline$A B-X V$ & C.(?) hatcheri & 125 & Translucent & 2.33 & 0.09 & -0.84 & 0.03 & 15.8 \\
\hline$A B-X V$ & C.(?) hatcheri & 126 & Chalky & -4.84 & 0.13 & -0.78 & 0.17 & -- \\
\hline$A B-X V$ & C.(?) hatcheri & 127 & Chalky & -7.23 & 0.05 & -18.82 & 0.06 & -- \\
\hline$A B-X V$ & C.(?) hatcheri & 128 & Chalky & -2.99 & 0.05 & -12.51 & 0.07 & -- \\
\hline$A B-X V$ & C.(?) hatcheri & 129 & Chalky & -3.95 & 0.06 & -17.45 & 0.06 & -- \\
\hline$A B-X V$ & C.(?) hatcheri & 130 & Chalky & -6.3 & 0.07 & -19.19 & 0.06 & -- \\
\hline
\end{tabular}

(Fig. 7). At the base of the succession the oxygen isotope composition of the translucent growth increments ranges from $-2 \%$ to $0.5 \%$; while in the upper part it ranges from $-5 \%$ to $0 \%$. The chalky growth increments are marked by very negative oxygen values in the upper part of the succession. The transition between these two zones, which is placed at $130 \mathrm{~m}$ from the base of the succession, is characterized by the absence of oyster shell beds and marks the change from C.(?) hatcheri to $C$. orbignyi (Fig. 7). This subdivision is also evident in the $\delta^{13} \mathrm{C}$ of the translucent growth increments, which show higher values in the lower part $(0 \%$ to $2 \%$ ) and lower values in the upper part (from $-4 \%$ to
$1 \%$ ). $\delta^{13} \mathrm{C}$ data for the chalky growth increments have strongly negative values and an increase in the range of values toward the upper part of the section.

Consecutive intrashell microsampling reveals a similar pattern of variation between microstructures. Translucent growth increments show subtle variations in both $\delta^{18} \mathrm{O}$ and $\delta^{13} \mathrm{C}$ composition, with values around $-0.5 \%$ and $2 \%$, respectively, for one thick C.(?) hatcheri from the middle part of the Bandurrias Member (Fig. 6). By contrast, chalky growth increments highly deviate to negative values, especially for oxygen isotopic ratios, as is also observed in a specimen of C. orbignyi (Fig. 6). 


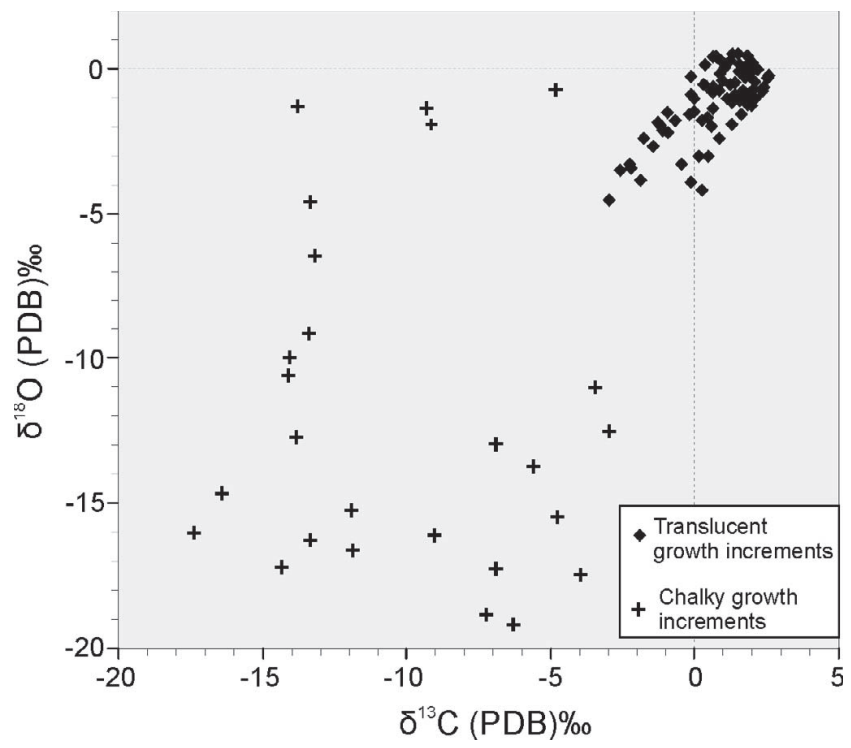

FIGURE 8-Cross plot of $\delta^{18} \mathrm{O}$ versus $\delta^{13} \mathrm{C}$ for the whole data set. Note the difference between chalky and translucent growth increments, and the anomalous negative values of both isotope ratios in the chalky growth increments.

\section{INTERPRETATION OF ISOTOPE DATA}

\section{Pristine versus Altered Biogenic Carbonate}

The original isotopic composition of an oyster should be in equilibrium with the isotopic composition and temperature of the ambient seawater (Kirby et al., 1998; Surge et al., 2001). A notable discrepancy between values from translucent and chalky growth increments of various shells, and within single shells, has been observed which cannot be explained by environmental factors. This suggests that one or the other microstructural isotopic composition is not original. Poor crystallinity (Fig. 5B), bright, orange luminescence (Fig. 5D), and highly spread isotopic composition (Fig. 8) of chalky growth increments suggest diagenetic alteration and modification of the original isotope composition, probably by interaction with sediment pore waters after burial. The low values recorded for both $\delta^{18} \mathrm{O}$ and $\delta^{13} \mathrm{C}$, especially in the upper part of the stratigraphic section (Fig. 7), suggest that pore waters were of meteoric origin (Mozley and Burns, 1993). On the other hand, while chalky growth increments were diagenetically modified, translucent growth increments probably reflect the original composition and temperature of the ancient seawater. The selective alteration relates to the original microstructure of the chalky growth increments, which are made of a low-density, porous net of calcite blades (Lee et al., 2009; MacDonald et al., 2010), produced by the oyster to achieve a lowweight material during episodes of rapid growth (Chinzei, 1986, 1995; Wang et al., 1995; Kirby, 2001). Isotopic values from chalky growth increments of modern oysters are in the same range as those of other microstructures in the same valve (Wang et al., 1995; Surge et al., 2001). The high range of variation of isotopic values in the chalky growth increments can be interpreted as the result of varying degrees of recrystallization of the pristine chalky material because these growth increments are more porous, more penetrable, and therefore more susceptible to alteration.

Petrographic and CL analysis indicate that foliated and prismatic (translucent) microstructures are well preserved, with little or no diagenetic alteration. This is also supported by the isotope values that do not deviate markedly from $0 \%$ for both $\delta^{18} \mathrm{O}$ and $\delta^{13} \mathrm{C}$, and are typical for Miocene shells that lived in marine and brackish waters (Savin et al., 1975; Veizer et al., 1999; Zachos et al., 2001).

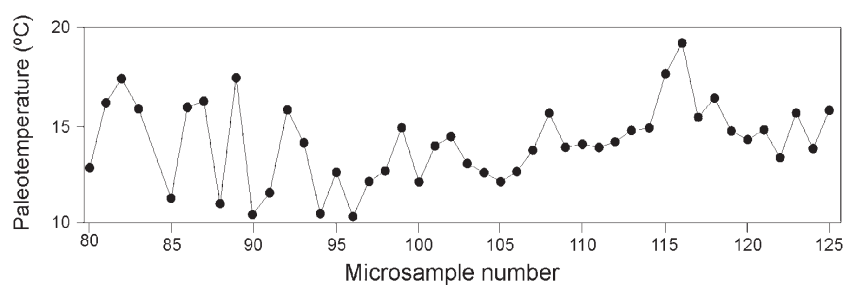

FIGURE 9-Paleotemperatures $\left({ }^{\circ} \mathrm{C}\right)$ calculated from the $\mathrm{AB}-\mathrm{XV}$ specimen shown in Figure 6A. Note high frequency fluctuation of data in earlier-formed growth increments (to the left) and lower-frequency fluctuation in the later-formed growth increments (to right).

\section{$\delta^{18} \mathrm{O}$ of Translucent Growth Increments}

The $\delta^{18} \mathrm{O}$ of the shell calcite is partly determined by that of the ambient seawater, which is controlled by evaporation and freshwater input (mainly fluvial runoff) into the basin. The $\delta^{18} \mathrm{O}$ values of the translucent growth increments from the $C$.(?) hatcheri shells in the lower part of the succession are typical of shells that lived in normal salinity marine waters. Variations within shells can be interpreted as the result of paleotemperature fluctuations during the life span of each specimen, and the paleotemperatures can be estimated based on calcitewater fractionation-factor equations (e.g., Epstein et al., 1953). Results vary from 10.6 to $20.5{ }^{\circ} \mathrm{C}$ from single (translucent) microsamples of C.(?) hatcheri shells over the lower two thirds of the sedimentary succession. Additionally, the same range of paleotemperatures is given by the 45 successive microsamples from the specimen AB-XV (Fig. 9), with a mean of $14.1{ }^{\circ} \mathrm{C}$. Each microsample represents a growth increment, revealing the variation of temperatures from earlier-secreted (about sample 80) to later-secreted (about sample 125) growth increments (Figs. 6A, 9). Although Parras and Casadío (2006) considered $C$.(?) hatcheri to have an approximately 25 year life span, the age of $\mathrm{AB}-\mathrm{XV}$ specimen is difficult to estimate because parts of the shell representing both early and late ontogeny are missing. These considerations, together with the number of growth increments, suggest that each isotopic value represents a time span of less than a year. A loss of high frequency fluctuation in temperature with time can be observed for this specimen (Fig. 9). This is interpreted as the result of decreasing shell-growth rates with age rather than a seawater paleotemperature variation, i.e., when the oyster grows older it secretes carbonate mainly during summers, and thus, winter temperatures are relatively less recorded. This pattern was called lengthened winter shutdown by Goodwin et al. (2003), and is a common feature among bivalves from subtropical settings (Jones and Quitmyer, 1996).

The present-day circulation regime along the southwestern Atlantic shelf is governed by the northward flow of cold waters of the Malvinas Current in the south and a southward flow of warm waters of the Brazil Current in the north (Matano et al., 2010). Our study area is presently located at $50^{\circ}-51^{\circ} \mathrm{S}$ (Fig. 1), where the Malvinas Current has a strong influence on the sea surface temperature (SST) regime in coastal areas (Matano et al., 2010; Piola et al., 2010). Nearshore, open SST at this latitude varies from 5 to $12{ }^{\circ} \mathrm{C}$ (http://iridl.ldeo.columbia.edu/; checked March 2013). In some shallow and restricted parts of the Patagonian shelf, the SST amplitude increases up to $13{ }^{\circ} \mathrm{C}$ (Podestá et al., 1991).

During the early Miocene (about $20 \mathrm{Ma}$ ), the composition and ${ }^{18} \mathrm{O}$ values of planktonic foraminiferal assemblages for the South Atlantic Ocean indicate that SSTs were warmer than today, but also warmer than in Oligocene and late Miocene times (Hodell and Kennett, 1985; Savin et al., 1985; Spezzaferri, 1995). The modeled SSTs are at least 3 ${ }^{\circ} \mathrm{C}$ higher than present day, but the pattern of oceanic currents was similar (von der Heydt and Dijkstra, 2006). A few paleotemperature estimations exist from the lower Miocene marine rocks of Patagonia. Malumián (1999), based on foraminiferal assemblages, suggested an influence of Antarctic waters during deposition of the Patagoniense 


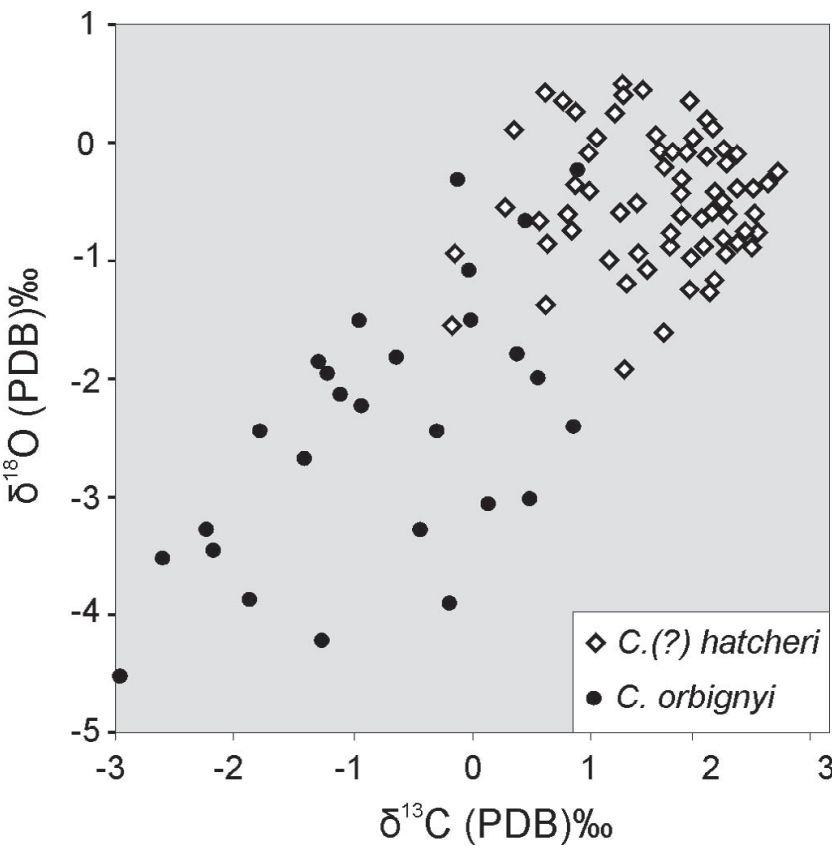

FIGURE 10-Cross plot of $\delta^{18} \mathrm{O}$ versus $\delta^{13} \mathrm{C}$ for microsamples from translucen growth increments. Note the lack of correlation for $C$.(?) hatcheri values in contrast to the fairly strong positive correlation for $C$. orbignyi values.

beds. Casadío et al. (2000) reported $\delta^{18} \mathrm{O}$ paleotemperatures in the range of $15-21^{\circ} \mathrm{C}$ from a single oyster shell.

The oysters analyzed lived in shallow water, and the paleotemperatures calculated from their shell carbonate are estimated to be equal to sea surface paleotemperatures. The paleotemperatures between 10.5 to $20.5^{\circ} \mathrm{C}$ calculated here (Table 3 ) are broadly consistent with data from the literature (Hodell and Kennett, 1985; Savin et al., 1985; Spezzaferri, 1995), although the maximum temperatures are higher. This is probably caused by restricted circulation in shallow shelves and embayments, with subsequent higher SST seasonal amplitudes (e.g., Podestá et al., 1991). In addition, SST rise may have been caused by a southward shift of the warm paleo-Brazil current (Scasso et al., 2000). This resulted from the formation of the Miocene volcanic arc in the northern part of the South Scotia Ridge (Barker et al., 1982), thus impeding the northward circulation of cold paleo-Malvinas current.

The very negative $\delta^{18} \mathrm{O}$ values recorded near the top of the section from the translucent growth increments of $C$. orbignyi specimens cannot be interpreted in terms of paleotemperature, because it would require temperatures of approximately $40{ }^{\circ} \mathrm{C}$. These values are interpreted to be the result of paleosalinity reduction. Supply of fresh water by fluvial discharge is the most reasonable cause for the depletion in ${ }^{18} \mathrm{O}$ in the seawater of the estuaries where the oysters grew. We cannot estimate paleosalinity of the estuary because the isotopic composition of the freshwater supplied to the estuary and its temperature are unknown. A rainfall highly depleted in ${ }^{18} \mathrm{O}$ would be expected considering the high paleolatitude for this locality (Bowen and Wilkinson, 2002). Relatively small amounts of freshwater supplied to the sea would have produced a considerable modification of the stable isotope composition of the water in the coastal-estuarine zone. Thus, the $\delta^{18} \mathrm{O}$ composition of the $C$. orbignyi shells is mainly the result of the mixing of fresh and marine waters in varying amounts. Many samples yielded values typical of shells living in normal marine water, suggesting that the salinity in the study interval varied from fully marine to brackish. The oysters likely halted secretion of carbonate during peaks of fluvial discharge, a strategy observed in some modern oysters and other bivalves (Calvo et al., 2000; Gillikin et al., 2005). Thus, the $\delta^{18} \mathrm{O}$ of shell carbonate probably does not represent the full range of salinity experienced by the oysters.

Subsequent studies using independent temperature proxies such $\mathrm{Mg} /$ $\mathrm{Ca}$ values, are required to confirm the reconstructed temperature and paleosalinity estimates for each species.

\section{$\delta^{13} \mathrm{C}$ of Translucent Growth Increments}

The $\delta^{13} \mathrm{C}$ composition of marine carbonates depends upon the ${ }^{13} \mathrm{C} /{ }^{12} \mathrm{C}$ ratio of the source carbon. One of the most important controlling variables in aquatic settings is phytoplankton growth, which withdraws relatively ${ }^{12} \mathrm{C}$-rich carbon from the water and consequently leaves it relatively enriched in ${ }^{13} \mathrm{C}$ (Wang et al., 1995). Dissolved inorganic carbon in the ambient water is typically the main source of carbon within shells. For bivalves, a maximum of $10 \%$ of the $\delta^{13} \mathrm{C}$ of the shell carbonate comes from metabolic carbon (McConnaughey and Gillikin, 2008). For the lower two thirds of the succession (data from C.(?) hatcheri), values of $\delta^{13} \mathrm{C}$ are typical of the isotopic composition of the ocean dissolved inorganic carbon (Wang et al., 1995). Positive correlation between $\delta^{13} \mathrm{C}$ and $\delta^{18} \mathrm{O}$ values in C. orbignyi (Fig. 10) may mean (1) higher rates of respiration/decay of organic carbon on the sea floor under warmer conditions (leading to lower $\delta^{13} \mathrm{C}$ of the adjacent water); (2) greater incorporation of carbon from metabolic sources (low $\delta^{13} \mathrm{C}$ because it ultimately derives from phytoplankton) under warmer conditions; or (3) control of $\delta^{18} \mathrm{O}_{c}$ and $\delta^{13} \mathrm{C}_{\mathrm{c}}$ by the supply of freshwater. This type of correlation was not registered in $C$.(?) hatcheri translucent growth increments (Fig. 10), but for the AB-XV specimen, the earlier-formed growth increments record a high-frequency fluctuation of both isotope values; whereas the later-formed ones show a lower-frequency fluctuation (Fig. 5). This pattern can be explained through differences in growth rates as for $\delta^{18} \mathrm{O}$.

The $C$. orbignyi in the upper part of the section have more negative $\delta^{13} \mathrm{C}$ values than in the lower part of the section, and show the influence of organic-derived carbon. This can be interpreted as the result of freshwater supply into the estuarine system. Freshwater is enriched in light carbon due to vegetal oxidation in terrestrial settings. Therefore, $\delta^{13} \mathrm{C}$ values and the $\delta^{13} \mathrm{C}-\delta^{18} \mathrm{O}$ positive correlation also support the hypothesis that $C$. orbignyi lived in an environment subjected to reductions in salinity.

\section{IMPLICATIONS OF ISOTOPE ANALYSIS FOR THE PALEOENVIRONMENTAL RECONSTRUCTION}

Facies and isotopic analyses point to salinity as the major control over the distribution of the two oyster species. Taphonomic attributes of $C$.(?) hatcheri accumulations vary according to the different sedimentary environments, although the isotopic analysis indicates that all specimens developed under conditions of normal marine salinity. These conditions are also suggested by the large size and thickness of the shell, interpreted as an adaptation to avoid marine predation, which comprised a considerable threat in Cenozoic shallowmarine settings (Kirby, 2000, 2001). Facies analysis proves that $C$.(?) hatcheri grew in nearshore, shallow-marine environments, sometimes associated with a rich and diverse marine fauna (bivalves, gastropods, echinoderms, crustaceans, etc.) but also (in the Bandurrias Member) as monospecific communities associated with estuarine deposits. Commonly, low-diversity or monospecific shell beds are related to environmental stress, commonly due to fresh-water input in coastal settings. Monospecific shell beds of $C$.(?) hatcheri with marine isotopic signatures may have accumulated in environments that experienced small and short salinity reductions due to fresh-water input. This oyster may have stopped secreting carbonate during unfavorable low-salinity events, thus recording only normal marine salinity intervals in the isotope ratios of its shells. The fact that modern oysters secrete their shell carbonate under brackish-water conditions (Calvo et al., 1999; 
Kirby, 2000; Surge et al., 2001) argues against this scenario. Alternatively, the environment may have remained continuously marine and the shell beds may represent episodes of rapid colonization and growth at times when substrate conditions were favorable and other organisms were excluded by the abundance of oysters. This scenario has been postulated to occur commonly after short transgressive events in shallow-marine systems (Pufahl and James, 2006). Therefore, rapid community growth is the most sound and reliable hypothesis on the basis of the constant isotope ratios and the large size of the shells of $C$.(?) hatcheri in the Bandurrias Member, together with the highly dynamic, tide-dominated estuarine environment.

Crassostrea orbignyi accumulations are restricted to a narrow stratigraphic section in the transition from marine to fluvial environments. Sedimentologic, taphonomic, and isotopic data reveal that this oyster grew in low-energy, muddy intertidal estuarine environments subjected to frequent fluctuations in salinity. Isotopic data suggest that this oyster secreted part of its shell during periods of reduced salinity, which seem to have been a frequent condition during the oyster's life. Shell secretion in low-salinity waters is an adaptive advantage that allows oysters to live in environments inaccessible for many other species. Low-salinity settings provide a refuge from bioerosion, as evidenced by the lack of this in C. orbignyi shells. Similar observations were made by Kirby (2001) on other Crassostrea species, pointing out also that the estuarine environment serves as a refuge from marine predators.

Kirby (2001) suggested that chalky layers in marine oysters are the result of fast growth and concomitant quick increase in shell thickness, in order to escape from shell-boring organisms. In our case, chalky layers are rare in the fully marine oysters, even in specimens with giant shells. On the contrary, thinner $C$. orbignyi shells in brackish settings are made, in some cases, almost entirely of chalky deposits. From the evidence of the nature of the substrates where each oyster species grew (see section Oyster Accumulations; Figs. 2, 7), chalky deposition in the Estancia 25 de Mayo Formation seems to have been an adaptation for reducing the shell weight in order to live on muddy soft grounds (e.g., Chinzei, 1995).

\section{CONCLUSIONS}

The Estancia 25 de Mayo Formation includes numerous oysterbearing levels, intercalated in shallow-marine deposits that range from offshore to intertidal estuarine environments as part of a transgressiveregressive cycle. Two species of oysters were identified showing separate stratigraphic distributions: in the lower two thirds of the sequence occurs Crassostrea(?) hatcheri; whereas C. orbignyi is limited to the upper third of the section. The species show differences in shell morphology, mode of preservation and paleoenvironmental setting.

Detailed observation of the internal microstructure of the oyster shells facilitates recognition of two main types of microstructures: translucent (foliated and prismatic) and chalky microstructures. Both types are present in both species, although translucent growth increments dominate in the C.(?) hatcheri shells; whereas chalky growth increments dominate in the $C$. orbignyi shells.

Carbon and oxygen isotope analyses of single layers reveal a strong microstructural control over the isotopic composition: chalky growth increments underwent varying degrees of diagenetic recrystallization, altering the original isotopic composition, while translucent growth increments values record paleoenvironmental conditions of formation.

The isotopic values of the translucent growth increments differ for each oyster species. The data for C.(?) hatcheri indicate carbonate secretion in normal marine waters. Paleotemperatures calculated from $\delta^{18} \mathrm{O}$ range from 10.6 to $20.5^{\circ} \mathrm{C}$. On the other hand, C. orbignyi isotope ratios are depleted, pointing to frequent reductions in paleosalinity. The elevated paleotemperatures calculated from oxygen isotopic data suggest the effect of warm oceanic currents affecting the lower Miocene
Patagonian shelf, as well as the restriction of oceanic circulation within nearshore embayments

Integrated facies analysis and stable isotope geochemistry yielded useful insights into the paleoenvironmental factors that control the development of distinct oyster communities. Low taxonomic diversity in normal marine waters resulted from the opportunistic character of the oysters and rapid community growth; whereas in estuarine brackish-water settings, the low benthic diversity is the product of paleosalinity fluctuations.

\section{ACKNOWLEDGMENTS}

We want to acknowledge Daniel Poiré for his invaluable logistic support during field work, Murilo Bastos for his help during laboratory procedures, Eduardo Llambias for oyster preparations, and Sergio Matheos for his help in the CL studies. This study was funded by grants of the Consejo Nacional de Investigaciones Científicas y Técnicas (CONICET) and the Agencia Nacional de Promoción Científica y Tecnológica (ANPCyT) of Argentina.

\section{REFERENCES}

Barker, P.F., Hill, I.A., Weaver, S.D., and Pankhurst, R.J., 1982, The origin of the eastern South Scotia Ridge as an intraoceanic island arc, in Craddok, C., ed., Antarctic Geoscience Symposium on Antarctic Geology and Geophysics: University of Wisconsin Press, Madison, Wisconsin, p. 203-211.

Barreda, V.D., Palazzesi, L., and Marenssi, S., 2009, Palynological record of the Paleogene Río Leona Formation (southernmost South America): Stratigraphical and paleoenvironmental implications: Review of Palaeobotany and Palynology, v. 151, p. $22-33$.

Bellosi, E.S., 1996, Arrecifes de ostras gigantes en depósitos de albúfera de la Formación Chenque (Mioceno inferior, Cuenca San Jorge): Sixth Argentinean Meeting of Sedimentology, Abstracts, p. 181-186.

Billups, K., and D. P. Schrag, 2002, Paleotemperatures and ice volume of the past 27 Myr revisited with paired $\mathrm{Mg} / \mathrm{Ca}$ and ${ }^{18} \mathrm{O} /{ }^{16} \mathrm{O}$ measurements on benthic foraminifera: Paleoceanography, v. 17(1), 1003, doi:10.1029/2000PA000567.

Bowen, G.J., and Wilkinson, B., 2002, Spatial distribution of $\delta^{18} \mathrm{O}$ in meteoric precipitation: Geology, v. 30, p. 315-318

Calvo, G.W., Luckenbach, M.W., Allen, S.K., and Burreson, E.M., 1999, Comparative field study of Crassostrea gigas (Thunberg, 1793) and Crassostrea virginica (Gmelin, 1791) in relation to salinity in Virginia: Journal of Shellfish Research, v. 18, p. 465-473.

Calvo, G.W., Luckenbach, M.W., Allen, S.K., and Burreson, E.M., 2000, A Comparative Field Study of Crassostrea ariakensis and Crassostrea virginica in Relation to Salinity in Virginia: School of Marine Science Virginia Institute of Marine Science, Special Report in Applied Marine Science and Ocean Engineering No. 360,25 p.

CARter, J.G., 1990, Shell microstructural data for the Bivalvia, in Carter, J.G., ed., Skeletal Biomineralization: Patterns, Processes and Evolutionary Trends, vol. 1: Van Nostrand Reinhold, New York, p. 297-391.

Casadío, S., Feldmann, R., and Foland, K., 2000, ${ }^{40} \mathrm{Ar} /{ }^{39} \mathrm{Ar}$ age and oxygen isotope temperature of the Centinela Formation, southwestern Argentina: An Eocene age for crustacean-rich "Patagonian" beds: Journal of South American Earth Sciences, v. 13 , p. $123-132$

CHinZEI, K., 1986, Shell structure, growth, and functional morphology of an elongate cretaceous oyster: Palaeontology, v. 29, p. 139-154.

ChinzeI, K., 1995, Adaptive significance of the lightweight shell structure in soft bottom oysters: Neues Jahrbuch für Geologie und Paläontologie, Abhandlungen, v. 195 , p. $217-227$.

Cuitiño, J.I., 2011, Registro sedimentológico e isotópico de paleoambientes marinos y transicionales en el Patagoniano (Mioceno) del Lago Argentino: Unpublished Doctoral thesis, University of Buenos Aires, Buenos Aires, 263 p.

Cuitiño, J.I., and Scasso, R.A., 2010, Sedimentología y paleoambientes del Patagoniano y su transición a la Formación Santa Cruz al sur del Lago Argentino, Patagonia Austral: Revista de la Asociación Geológica Argentina, v. 66, p. 406417.

Cuitiño, J.I., and SCASSO, R.A., 2013, Reworked pyroclastic beds in the early Miocene of Patagonia: Reaction in response to high sediment supply during explosive volcanic events: Sedimentary Geology, v. 289, p. 194-209.

Cuitiño, J.I., Pimentel, M.M., Ventura Santos, R., and Scasso, R.A., 2012, High resolution isotopic ages for the "Patagoniense transgression" in southwest 
Patagonia: Stratigraphic implications: Journal of South American Earth Sciences, v. 38 , p. $110-122$.

Dalrymple, R.W., and Chol, K., 2007, Morphologic and facies trends through the fluvial-marine transition in tide-dominated depositional systems: A schematic framework for environmental and sequence-stratigraphic interpretation: EarthScience Reviews, v. 81, p. 135-174.

Dalrymple, R.W., Zaituin, B.A., and Boyd, R., 1992, Estuarine facies models: Conceptual basis and stratigraphic implications: Journal of Sedimentary Petrology, v. 62 , p. $1130-1146$.

Epstein, S., Buchsbaum, R., Lowenstam, H.A., and Urey, H.C., 1953, Revised carbonate-water temperature scale: Bulletin of the Geological Society of America, v. 64, p. 1315-1328.

Fosdick, J.C., Romans, B.W., Fildani, A., Bernhardt, A., Calderón, M., and Graham, S.A., 2011, Kinematic evolution of the Patagonian retroarc fold-andthrust belt and Magallanes foreland basin, Chile and Argentina, $51^{\circ} 30^{\prime} \mathrm{S}$ : Geological Society of America Bulletin, v. 123, p. 1679-1698.

Gibuing, M.R., 2006, Width and thickness of fluvial channel bodies and valley fills in the geological record: A literature compilation and classification: Journal of Sedimentary Research, v. 76, p. 731-770.

Gillikin, D.P., Ridder, F.D., Ulens, H., Elskens, M., Keppens, E., Baeyens, W., and Dehairs, F., 2005, Assessing the reproducibility and reliability of estuarine bivalve shells (Saxidomus giganteus) for sea surface temperature reconstruction: Implications for paleoclimate studies: Palaeogeography, Palaeoclimatology, Palaeoecology, v. 228, p. 70-85.

Goodwin, D.H., Schöne, B.R., and Dettman, D.L., 2003, Resolution and fidelity of oxygen isotopes as paleotemperature proxies in bivalve mollusk shells: Models and observations: PALAIOS, v. 18, p. 110-125.

Hampson, G.J., and Storms, J.E.A., 2003, Geomorphological and sequence stratigraphic variability in wave-dominated, shoreface-shelf parasequences: Sedimentology, v. 50, p. 667-701.

Higuera-Ruiz, R., and Elorza, J., 2009, Biometric, microstructural, and highresolution trace element studies in Crassostrea gigas of Cantabria (Bay of Biscay, Spain): Anthropogenic and seasonal influences: Estuarine, Coastal and Shelf Science, v. 82, p. 201-213.

Hodell, D.A., and KennetT, J.P., 1985, Miocene paleoceanography of the South Atlantic Ocean at 22, 16 and Ma, in Kennett, J.P., ed., The Miocene Ocean: Paleoceanography and Biogeography: Geological Society of America, Memoir 163 , p. $317-337$.

Ihering, H. von, 1897, Os molluscos dos terrenos terciarios da Patagonia: Revista do Museu Paulista, v. 2, p. 217-382

Jones, D.S., and Quitmyer, I.R., 1996, Marking time with bivalve shells: Oxygen isotopes and season of annual increment formation: PALAIOS, v. 11, p. $340-346$

Kidwell, S.M., 1991, The stratigraphy of shell concentrations, in Allison, P.A., and Briggs, D.E.G., eds., Taphonomy: Releasing the Data Locked in the Fossil Record: Topics in Geobiology, vol. 9: Plenum Publishing, New York, p. 211-290.

Kirby, M.X., 2000, Paleoecological differences between Tertiary and Quaternary Crassostrea oysters, as revealed by stable isotope sclerochronology: PALAIOS, v. 15, p. $132-141$.

KIRBY, M.X., 2001, Differences in growth rate and environment between Tertiary and Quaternary Crassostrea oysters: Paleobiology, v. 27, p. 84-103.

Kirby, M.X., Soniat, T.M., and Spero, H.J., 1998, Stable isotope sclerochronology of Pleistocene and Recent oyster shells (Crassostrea virginica): PALAIOS, v. 13, p. $560-569$.

Lee, S.W., KAnG, G., LeE, K.B., and PARK, S.B., 2009, New approach for fabrication of folded-structure $\mathrm{SiO}_{2}$ using oyster shell: Micron, v. 40, p. 713-718.

MacDonald, J., Freer, A., and Cusack, M., 2010, Alignment of crystallographic caxis throughout the four distinct microstructural layers of the oyster Crassostred gigas: Crystal Growth and Design, v. 10, p. 1243-1246.

MaKaske, B., 2001, Anastomosing rivers: A review of their classification, origin and sedimentary products: Earth-Science Reviews, v. 53, p. 149-196.

Malumián, N., 1999, La sedimentación en la Patagonia extraandina, in Caminos, R., ed., Geología Argentina: Instituto de Geología y Recursos Minerales, annals 29, p. 557-612.

Marenssi, S.A., Limarino, C.O., Tripaldi, A., and Net, L.I., 2005, Fluvial systems variations in the Río Leona Formation: Tectonic and eustatic controls on the Oligocene evolution of the Austral (Magallanes) Basin, southernmost Argentina: Journal of South American Earth Sciences, v. 19, p. 359-372.

Matano, R.P., Palma, E.D., and Piola, A.R., 2010, The influence of the Brazil and Malvinas Currents on the Southwestern Atlantic Shelf circulation: Ocean Science, v. 6, p. 983-995.

McConnaughey, T.A., and Gillikin, D.P., 2008, Carbon isotopes in mollusk shel carbonates: Geo-Marine Letters, v. 28, p. 287-299.

Miall, A.D., 1996, The Geology of Fluvial Deposits. Sedimentary Facies, Basin Analysis, and Petroleum Geology: Springer-Verlag, Berlin, 582 p.
Mozley, P.S., and Burns, S.J., 1993, Oxygen and carbon isotopic composition of marine carbonate concretions: An overview: Journal of Sedimentary Petrology, v. 63 , p. $73-83$.

Nelson, C.S., Burns, D.A., and Rodgers, K.A., 1983, The taxonomic status, and isotopic evidence for paleoenvironments, of giant oysters from the Oligocene $\mathrm{Te}$ Kuiti Group, South Auckland, New Zealand: New Zealand Journal of Geology and Geophysics, v. 26, p. 289-299.

Nio, S.D., and YANG, C.S., 1991, Diagnostic attributes of clastic tidal deposits: a review, in Smith, D.G., Reinson, G.E., Zaitlin, B.A., and Rahmani, R.A., eds, Clastic Tidal Sedimentology, Canadian Society of Petroleum Geologists, Memoir, v. 16 , p. $3-28$.

Norris, R.D., 1986, Taphonomic gradients in shelf fossil assemblages: Pliocene Purisima Formation, California: PALAIOS, v. 1, p. 256-270.

Ortmann, A.E., 1897, On some of the large oysters of Patagonia: American Journal of Science, v. 4, p. 355-357.

Parras, A., and Casadío, S., 2005, Taphonomy and sequence stratigraphic significance of oyster-dominated concentrations from the San Julián formation, Oligocene of Patagonia, Argentina: Palaeogeography, Palaeoclimatology, Palaeoecology, v. 217 , p. $47-66$.

Parras, A., and Casadío, S., 2006, The oyster Crassostrea? hatcheri (Ortmann, 1897), a physical ecosystem engineer from the upper Oligocene-lower Miocene of Patagonia, southern Argentina: PALAIOS, v. 21, p. 168-186.

Parras, A., Griffin, M., and Guerstein, R., 2008, Significado paleoambiental de concentraciones de Crassostrea orbignyi (Ihering, 1897), en el Mioceno inferior de sur de Patagonia, Argentina: Twelfth Argentinean Meeting of Sedimentology, Abstracts, Buenos Aires, p. 136

Parras, A., Dix, G., and Griffin, M., 2012, Sr-isotope chronostratigraphy of Paleogene-Neogene marine deposits: Austral Basin, southern Patagonia (Argentina): Journal of South American Earth Sciences, v. 37, p. 122-135.

Pemberton, S.G., Spila, M., Pulham, A.J., Saunders, T., MacEachern, J.A., Robisns, D., and Sinclair, I.K., 2001, Ichnology and sedimentology of shallow to marginal marine systems: Ben Nevis and Avalon reservoirs, Jeanne d'Arc Basin: Geological Association of Canada, Short Course Notes 15, 356 p.

Piola, A R. Martínez-Avellaneda, N., Guerrero, R.A., Jardón, F P., Palma, E.D., and Romero, S.I., 2010, Malvinas-slope water intrusions on the northern Patagonia continental shelf: Ocean Science, v. 6, p. 345-359.

Podestá, G.P., Brown, O.T., and Evans, R.H., 1991, The annual cycle of satellitederived sea surface temperature in the southwestern Atlantic Ocean: Journal of Climate, v. 4, p. 457-467.

Pufahl, P.K., and James, N.P., 2006, Monospecific Pliocene oyster buildups, Murray Basin, South Australia: Brackish water end member of the reef spectrum: Palaeogeography, Palaeoclimatology, Palaeoecology, v. 233, p. 11-33.

Savin, S.M., Douglas, R.G., and Stehli, F.G., 1975, Tertiary marine paleotemperatures: Geological Society of America Bulletin, v. 86, p. 1499-1510.

Savin, S.M., Abel, L., Barrera, E., Hodell, D., Keller, G., Kennett, J.P., Killingley, J., Murphy, M., and Vincent, E., 1985, The evolution of Miocene surface and near-surface marine temperatures: Oxygen isotopic evidence, in Kennett, J.P., ed., The Miocene Ocean: Paleoceanography and Biogeography: Geological Society of America, Memoir 163, p. 49-82.

Scasso, R.A., Castro, L.N., and Tofalo, O.R., 2000, Phosphogenesis, sequence stratigraphy and paleoceanography of Cenozoic phosphates from Gaiman Formation, Patagonia, Argentina, 31st International Geological Congress, Rio de Janeiro, Brazil, Abstracts CD ROM

SCHÖNE, B.R., 2008, The curse of physiology: Challenges and opportunities in the interpretation of geochemical data from mollusk shells: Geo-Marine Letters, v. 28, p. $269-285$.

Schöne, B.R., and Surge, D., 2012, Part N (Mollusca, Bivalvia), Revised, Volume 1, Chapter 14: Bivalve sclerochronology and geochemistry: Treatise Online, v. 46, p. 1-24

SPEZZAFERRI, S., 1995, Planktonic foraminiferal paleoclimatic implications across the Oligocene-Miocene transition in the oceanic record (Atlantic, Indian and South Pacific): Palaeogeography, Palaeoclimatology, Palaeoecology, v. 114, p. 43-74.

Stenzel, H., 1971, Oysters, in Moore, R.C., and Teichert, C., eds., Treatise of Invertebrate Paleontology, Part N, Mollusca 6, Bivalvia 3, Geological Society of America and University of Kansas, Boulder, Colorado and Lawrence, Kansas, p. $953-1224$

Surge, D., Lohmann, K.C., and Dettman, D.L., 2001, Controls on isotopic chemistry of the American oyster, Crassostrea virginica: Implication for growth patterns: Palaeogeography, Palaeoclimatology, Palaeoecology, v. 172, p. 283-296. van den Berg, J.H., Boersma, J.R., and van Gelder, A., 2007, Diagnostic sedimentary structures of the fluvial-tidal transition zone: Evidence from deposits of the Rhine and Meuse: Netherlands Journal of Geosciences-Geologie en Mijnbouw, v. 86, p. 287-306.

Veizer, J., Davin, A., Azmy, K., Bruckschen, P., Buhl, D., Bruhn, F., Carden, G.A.F., Diener, A., Ebneth, S., Godderis, Y., Jasper, T., Korte, Ch., Pawellek, P., 
Podlaha, O.G., and Strauss, H., $1999,{ }^{87} \mathrm{Sr} /{ }^{86} \mathrm{Sr}, \delta^{13} \mathrm{C}$ and $\delta^{18} \mathrm{O}$ evolution of Phanerozoic seawater: Chemical Geology v. 161, p. 59-88.

von DER Heydt, A., and DiJKsTRA, H.A., 2006, Effect of ocean gateways on the global ocean circulation in the late Oligocene and early Miocene: Paleoceanography, v. 21, PA1011, doi: 10.1029/2005PA001149.

Wang, H., Keppens, E., Nielsen, P., and van Riet, A., 1995, Oxygen and carbon isotope study of the Holocene oyster reefs and paleoenvironmental reconstruction on the northwest coast of Bohai Bay, China: Marine Geology, v. 124, p. 289-302.

Weimer, R.J., Howard, J.D., and LindSAY, D.R., 1982, Tidal flats and associated tidal channels, in Scholle, P.A., and Spearing, D., eds., Sandstone depositional environments: American Association of Petroleum Geologists, Memoir 31, p. 191-245.
Yoshida, S., Johnson, H.D., Pye, K., and Dixon, R.J., 2004, Transgressive changes from tidal estuarine to marine embayment depositional systems: The Lower Cretaceous Woburn Sands of southern England and comparison with Holocene analogs: American Association of Petroleum Geologists Bulletin, v. 88, p. 14331460.

Zachos, J., Pagani, M., Sloan, L., Thomas, E., and Billups, K., 2001, Trends, rhythms, and aberrations in global climate 65 Ma to present: Science, v. 292, p. 686-693.

ACCEPTED JULY 8, 2013 